\title{
Plant-Derived Products for Treatment of Vascular Intima Hyperplasia Selectively Inhibit Vascular Smooth Muscle Cell Functions
}

\author{
Kang Xu $\mathbb{D}^{1},{ }^{1}$ Mohanad Kh Al-ani $\mathbb{D}^{2,3}$ Xin Pan ${ }^{2},{ }^{4}$ Qingjia Chi $\mathbb{D},{ }^{5}$ Nianguo Dong, \\ and Xuefeng Qiu (D) \\ ${ }^{1}$ Department of Cardiovascular Surgery, Union Hospital, Tongji Medical College, \\ Huazhong University of Science and Technology, Wuhan 430022, China \\ ${ }^{2}$ Tikrit University, College of Medicine, Department of Microbiology, P.O. Box 45, Salahaddin Province, Tikrit, Iraq \\ ${ }^{3}$ National Innovation and Attracting Talents "111" Base, Key Laboratory of Biorheological Science and Technology, \\ Ministry of Education, College of Bioengineering, Chongqing University, Chongqing 400030, China \\ ${ }^{4}$ National Demonstration Center for Experimental Ethnopharmacology Education, \\ College of Pharmacy, South-Central University for Nationalities, Wuhan 430074, China \\ ${ }^{5}$ Department of Mechanics and Engineering Structure, Hubei Key Laboratory of Theory and \\ Application of Advanced Materials Mechanics, Wuhan University of Technology, China \\ Correspondence should be addressed to Xuefeng Qiu; xuefeng_qiu@hust.edu.cn
}

Received 31 May 2018; Revised 1 September 2018; Accepted 20 September 2018; Published 11 October 2018

Academic Editor: Darren R. Williams

Copyright @ 2018 Kang Xu et al. This is an open access article distributed under the Creative Commons Attribution License, which permits unrestricted use, distribution, and reproduction in any medium, provided the original work is properly cited.

\begin{abstract}
Natural products are used widely for preventing intimal hyperplasia (IH), a common cardiovascular disease. Four different cells initiate and progress IH, namely, vascular smooth muscle, adventitial and endothelial cells, and circulation or bone marrow-derived cells. Vascular smooth muscle cells (VSMCs) play a critical role in initiation and development of intimal thickening and formation of neointimal hyperplasia. In this review, we describe the different originating cells involved in vascular IH and emphasize the effect of different natural products on inhibiting abnormal cellular functions, such as VSMC proliferation and migration. We further present a classification for the different natural products like phenols, flavonoids, terpenes, and alkaloids that suppress VSMC growth. Abnormal VSMC physiology involves disturbance in MAPKs, PI3K/AKT, JAK-STAT, FAK, and NF- $\kappa$ B signal pathways. Most of the natural isolate studies have revealed G1/S phase of cell cycle arrest, decreased ROS production, induced cell apoptosis, restrained migration, and downregulated collagen deposition. It is necessary to screen optimal drugs from natural sources that preferentially inhibit VSMC rather than vascular endothelial cell growth to prevent early $\mathrm{IH}$, restenosis following graft implantation, and atherosclerotic diseases.
\end{abstract}

\section{Introduction}

Intimal hyperplasia ( $\mathrm{IH})$ is a fibroproliferative disorder observed in vascular pathogenesis particularly in vessel anastomotic stenosis, atherosclerosis, blockage of vessel grafts, angioplasty, and in-stent restenosis [1]. IH is characterized by enhanced cell migration, proliferation, and differentiation that cause narrowing of the tunica intima. Several cells are associated with initiation and progression of $\mathrm{IH}$, namely, vascular smooth muscle cells (VSMCs) [2], vascular adventitial cells [3], vascular endothelial cells (VEC) [4], and circulating bone marrow-derived cells [5]. These cells have different origins but may contribute to IH formation. For example, endothelial cells may undergo endothelial-tomesenchymal transition (EndMT) acquiring a fibroproliferative mesenchymal phenotype whereas adventitia-derived stem cells may migrate to the intimal lesion site and differentiate into fibroblasts. VSMCs play a critical role in the initiation and development of intimal thickening and formation of neointimal hyperplasia $[6,7]$.

Many herbal medicines sourced from plants or foods have been used to prevent cardiovascular disease over the millennia. For example, green tea contains various flavanols that have antioxidative $[8,9]$, anti-inflammatory 
[10], antimicrobial [11], and hypolipidemic [9] effects. This pharmacological profile helps prevent atherosclerotic plaque formation caused by inflammation and oxidative stress. Red wine, another commonly enjoyed beverage, has long been believed to be rich in polyphenols [12], which act as powerful antioxidants. These assist in preventing lower density lipoprotein oxidation in heart disease and attenuating development of atherosclerotic disease in the hamster model $[13,14]$. Resveratrol (3,5,4'-trihydroxy-trans-stilbene), a typical polyphenol extracted from red wine, has been proven to inhibit proliferation of VSMCs in vitro [15]. Many natural compounds have been reported to be active and to have potential utility as clinical medicines. Tanshinone is an isolate from Salvia miltiorrhiza that has been used against cardiovascular disease in China [16]. Therefore, many active compounds with cosmopolitan distribution are being used as herbal medicines or foods, giving hope for screening for potential therapeutic agents against IH (Figure 1).

Recent clinical studies have shown that rapamycin A, an VSMC inhibitor, prevents development of $\mathrm{IH}$-induced vascular endothelial dysfunction [17]. This nonspecific cytotoxicity leads to stenosis and eventually to failure of vascular reconstruction after injury. Therefore, the ideal drug to prevent restenosis or IH is one that inhibits VSMC proliferation selectively while having minimal inhibitory effect on VEC proliferation.

\section{Diverse Cells Involved in Vascular IH}

As stated earlier, four different cell types are involved in the initiation and progression of IH. These are VSMCs, vascular adventitial cells, VECs, and circulating bone marrowderived cells (Figure 2). VSMCs play a critical role in the initiation of intimal thickening and the formation neointimal hyperplasia. Physiologically VSMCs exist in two phenotypes, i.e., differentiated cells and proliferating cells, which are responsible for maintaining the homeostasis and function of vascular vessels $[2,6]$. Stimulation by certain growth and inflammatory factors, such as platelet-derived growth factor, tumor necrosis factor- $\alpha$ (TNF- $\alpha$ ), and thrombin, results in dedifferentiation into mature VSMCs [18, 19]. Mature and differentiated VSMCs exhibit loss of contractility and increased proliferation and expression of ECM protein and various cytokines. This phenomenon is responsible for intimal thickening leading to the neointimal hyperplasia formation that is observed in early-phase atherosclerosis.

Endothelial-to-mesenchymal transition is a phenomenon where endothelial cells acquire a fibroproliferative mesenchymal phenotype through differential stimulation [20]. These transitioned endothelial cells mimic fibroblasts and have increased ECM production and migration capabilities. In vascular diseases, these transitioned endothelial cells can quickly migrate and differentiate into smooth muscle-like cells serving as a potential contributor to IH $[21,22]$. EMT is reported to be modulated by shear stress in an ERK5dependent manner, to contribute to neointimal hyperplasia, and to induce atherogenic differentiation [23]. In addition to adventitia-derived stem cells, circulating smooth muscle progenitor cells have also been implicated in the pathogenesis of neointimal hyperplasia [24] and in the recruitment of endothelial precursor cells after vascular trauma. The presence of bone marrow-derived cells in solid neointima or allograft lesions suggests their crucial involvement in lesion formation following vascular injury $[5,25]$. Although various cells contribute to IH pathogenesis, smooth muscle cells are the main culprits in lesion formation. Therefore, therapeutic strategies that maintain VSMCs in a terminally differentiated state and inhibit their proliferation and migration can be useful in preventing neointimal hyperplasia.

\section{Antiproliferation, Migration, and Cellular Functions of Abnormal VSMCs as a Target to Decrease Intimal Hyperplasia}

VSMCs in the normal vascular tunica media express a range of smooth muscle cell markers including smooth muscle cell myosin heavy chain (MYH11), 22-kDa SMC lineagerestricted protein (SM22 $\alpha / \operatorname{tagln})$, alpha smooth muscle actin (ACTA2), and smoothelin. VSMCs in vitro and in atherosclerosis undergo phenotypic switching with reduced expression of these markers, while increasing capacity for cell proliferation, migration, and secretion of various ECM proteins and cytokines. These phenotypic switches have long been considered of fundamental significance in IH progression.

Most studies investigating inhibition of VSMCs adopt drugs like rapamycin, sirolimus, or tacrolimus to induce VSMC apoptosis and cell cycle arrest at G1/S phase, suppress ROS production, inhibit VSMC migration, and downregulate collagen deposition. These approaches do not recover the mature VSMC immunophenotypes, but they do decrease neointimal formation and prevent stenosis following vascular injury. To investigate the anticellular function of drugs on VSMCs many models have been established in vitro and in vivo. For the in vitro experiments, inflammatory cytokines like TNF- $\alpha$ or some growth factors such as platelet-derived growth factor (PDGF) are used for inducing abnormal proliferation and migration of VSMCs. For the in vivo experiments, IH is usually induced using the vascular endothelial denudation model or carotid artery ligation injury.

Dietary supplements and traditional herbal medicines are complementary medication approaches used in every society and are widely used for preventing $\mathrm{IH}$ in Asia and in other developed countries [26]. Many herbal drugs and foods have been verified as suppressing abnormal VSMC growth and inhibiting intima formation. The positive effects of the herbal medicines and plants depend on their active natural compounds including phenols, flavonoids, terpenes, and alkaloids. These natural products are involved in different signaling pathways that regulate abnormal VMSCs to attenuate $\mathrm{IH}$.

\section{Typical Signal Pathways Involved in Growth and Physiology of VSMCs in IH Disease}

The six signaling pathways involved in most drug inhibitory VSMC studies (Figure 3) are mitogen-activated protein 


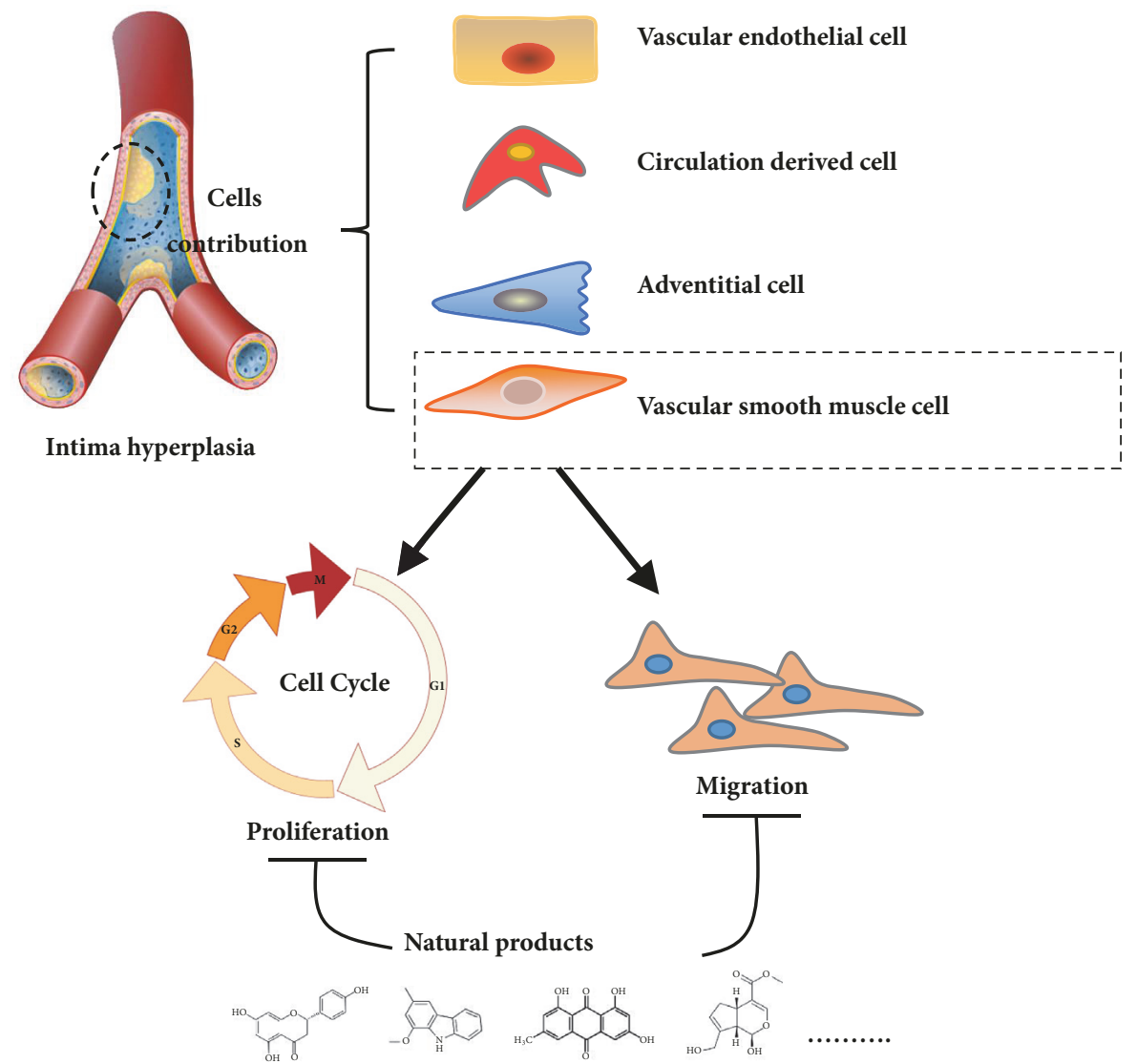

FIGURE 1: Graphic abstract for different natural compounds for inhibiting vascular smooth muscle cells proliferation and migration.

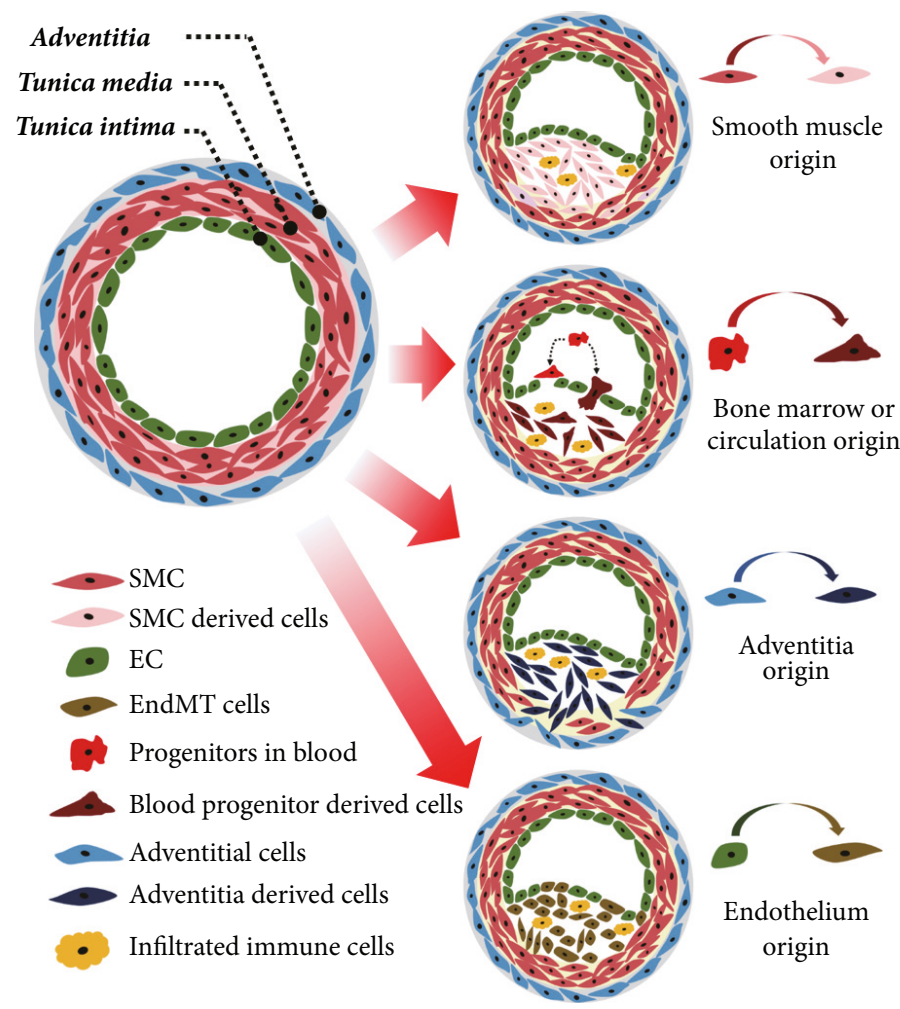

FiguRE 2: Four different cell origins contribute to blood vessel stenosis. 


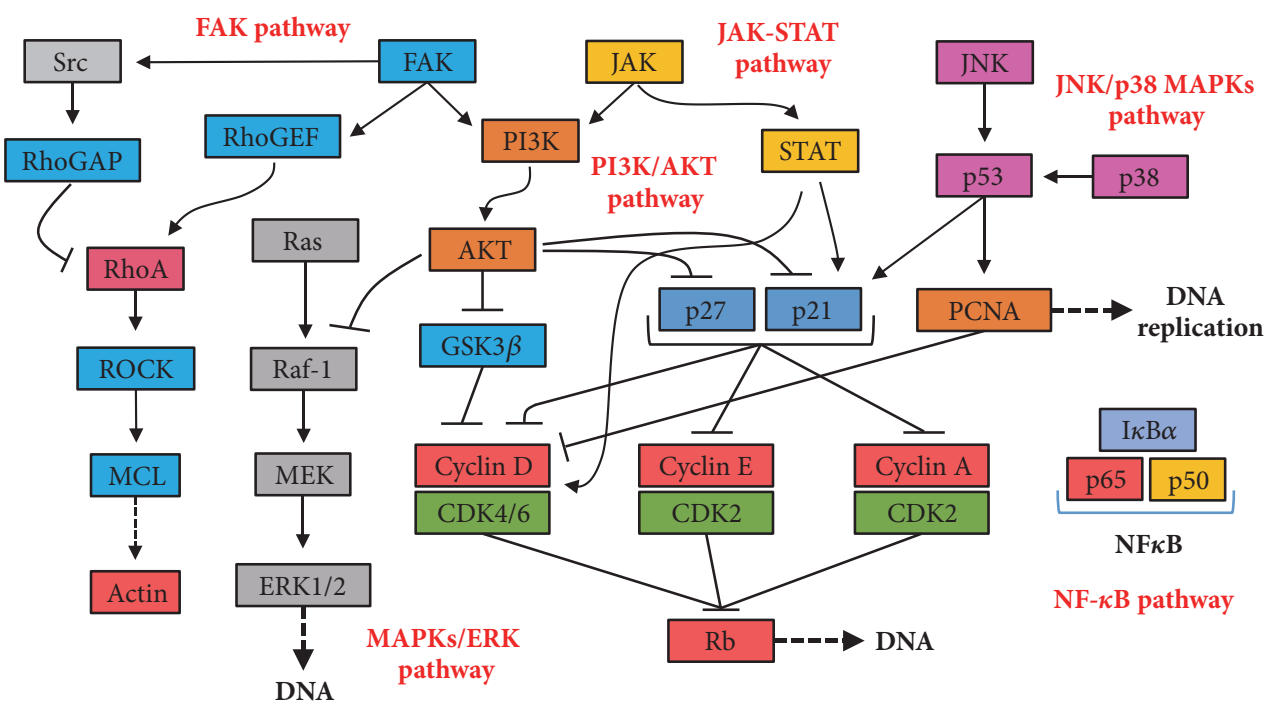

FIGURE 3: Key genes and pathways involved in restraining cell cycle and movements of VSMCs with natural products.

kinases/extracellular signal-regulated kinase (MAPKs/ERK), phosphatidylinositol 3-kinases/Akt (PI3K/Akt), Janus kinase-signal transducer and activator of transcription (JAK-STAT), focal adhesion kinase (FAK), and nuclear factor kappa-light-chain-enhancer of activated B (NF- $\kappa \mathrm{B})$. MAPKs are involved in cell proliferation, differentiation, mitosis, cell survival, and apoptosis [27]. Three major families of MAPKs are extracellular signal-regulated kinase (ERK) [28], p38 kinase, and c-Jun $\mathrm{N}$ terminal kinase (JNK). These contribute to the two important signaling pathways, Ras/ERK-MAPK and JNK/p38-MAPK, which are involved in regulating VSMCs [29]. In antiproliferation studies of VSMCs, PI3K/Akt signaling pathway includes many key factors such as GSK3 $\beta$, p21, and p27, which all inhibit cyclins and CDKs thereby interfering with cell cycle processes. GSK3 $\beta$ is one of the critical downstream molecules of the Akt signaling pathway involved in cell proliferation, metabolism, growth, and survival. It is reported that cyclin D is regulated by GSK3 $\beta$ [30] and that activation of GSK3 $\beta$ leads to exportation into cytoplasm for proteolysis, thus downregulating cyclin D1 expression [31]. The JAK-STAT signaling pathway transmits information from extracellular chemical signals to the nucleus resulting in DNA transcription and expression of genes involved in immunity, proliferation, differentiation, and apoptosis [32]. The downstream proteins in this pathway include cyclin D, p21, Bcl-2, and c-Myc, which are all directly involved in growth, apoptosis, and cell cycle progression in VSMC studies [33]. FAK is involved in cellular adhesion and migration [34]. FAK is typically located at structures known as focal adhesions, which are multiprotein structures including actin, filamin, and vinculin which link the ECM to the cytoplasmic cytoskeleton [35-37]. In addition, FAK interacts with PI3K and p53 [38, 39] and with the PI3K/Akt and MAPKs signaling pathways that are involved in cell cycle regulation. NF- $\kappa \mathrm{B}$ controls many genes involved with inflammation which are crucial to progression of diseases including arthritis, asthma, and atherosclerosis
[40, 41]. Inflammation also mediates abnormal movement and growth of VSMCs, while suppressing inflammation could attenuate neointimal hyperplasia significantly [42-45]. Therefore, different signaling pathways are involved in VSMC inhibition, which provides preferential protein targets for future drug screening.

\section{Different Natural Compounds Being Used for Preventing Neointimal Formation and Focus on VSMCs}

5.1. Flavonoids Regulate Cell Cycle and Functions Inhibiting VSMCs Proliferation and Migration. Flavonoids are distributed throughout the plant kingdom and fulfill a diverse range of biological and pharmacological effects such as antiinflammatory [46], antioxidant [47], antibacterial [48], antitumor [49], and antidiarrheal activities [50]. For treatment of cardiovascular disease, flavonoid studies have focused on reducing hypertension, risk of atherosclerosis, oxidative stress, and related signaling pathways in blood vessel cells, as well as modifying vascular inflammatory mechanisms $[51,52]$. In this review, we described the chemical structure, category, source, and mechanism of action of some typical flavonoids that suppress VSMC function and inhibit IH (Table 1).

Nobiletin is widely distributed in citrus fruits and has been reported to inhibit VSMC proliferation and migration in vitro [44]. In addition, carotid balloon injured rats given nobiletin $25 \mathrm{mg} / \mathrm{kg} /$ day by gavage had significantly decreased neointimal hyperplasia via regulation of the ROS derived NF- $\kappa \mathrm{B}$ pathway and decreased serum TNF- $\alpha$ and IL-6 concentrations [44]. Cyanidin-3-O-glucoside, an anthocyanin flavonoid, inhibited TNF- $\alpha$-induced NoxA1 (a type of NADPH oxidase) and downregulated expression of both TNF- $\alpha$ and NoxAl at transcriptional and translational levels [53]. (2S)-Naringenin, a typical flavonoid isolated from Typha angustata, inhibited PDGF-BB-induced proliferation 
TABLE 1: The structure, cells, category, source, and mechanism of typical flavonoid compounds on inhibiting VSMCs proliferation and migration.

\begin{tabular}{|c|c|c|c|c|c|}
\hline $\begin{array}{l}\text { Compound } \\
\text { name }\end{array}$ & Structure & Cells and animals & Category & Sources & Mechanism \\
\hline (2S)-naringenin & & rASMCs & Flavonoid & Typha angustata & $\begin{array}{c}\text { G0/G1 } \downarrow \text {; cyclins D1 } \downarrow \text {; } \\
\text { cyclins E } \downarrow \text {; CDK2 } / 4 \downarrow \text {; } \\
\text { PCNA } \downarrow \text {; pho of rb protein } \\
\downarrow\end{array}$ \\
\hline Catechins & & $\begin{array}{l}\text { rASMCs and rat } \\
\text { balloon injury }\end{array}$ & $\begin{array}{l}\text { Flavonoid } \\
\text { (Flavanols) }\end{array}$ & Green tea & $\begin{array}{c}\text { TIMP-2 } \uparrow, \text { in vivo: TIMP-2 } \\
\uparrow\end{array}$ \\
\hline Icariin & & hASMCs & $\begin{array}{c}\text { Flavonoid } \\
\text { (Prenylated } \\
\text { flavonol glycoside) }\end{array}$ & $\begin{array}{l}\text { Epimedium } \\
\text { brevicornum }\end{array}$ & $\mathrm{pERK} 1 / 2 \downarrow ; \mathrm{G} 1 / \mathrm{S} \downarrow ; \mathrm{PCNA} \downarrow$ \\
\hline Morelloflavone & & $\begin{array}{l}\text { mVSMCs and } \\
\text { mouse artery } \\
\text { injury }\end{array}$ & Biflavonoid & Garcinia dulcis & $\begin{array}{c}\text { FAK } \downarrow ; \text { Src } \downarrow ; \text { ERK } \downarrow \text {; RhoA } \\
\downarrow\end{array}$ \\
\hline Puerarin & & $\begin{array}{l}\text { rASMCs and rat } \\
\text { balloon injury }\end{array}$ & Isoflavone & Radix puerariae & $\begin{array}{c}\text { ROS } \downarrow \text {; Nox } \downarrow \text {; PKC;PKC } \beta 2 \\
\downarrow \text {; Rac1 } \downarrow \text {; p47phox } \downarrow ; \\
\text { p67phox } \downarrow\end{array}$ \\
\hline Kaempferol & & hpASMCs & Flavonoid & $\begin{array}{c}\text { Widely } \\
\text { (grapefruit, } \\
\text { Ginkgo biloba) }\end{array}$ & $\operatorname{miR}-21 \uparrow ; \mathrm{ROCK} 4 / 5 / 7 \downarrow$ \\
\hline Nobiletin & & $\begin{array}{l}\text { rASMCs and rat } \\
\text { balloon injury }\end{array}$ & Flavonoid & $\begin{array}{l}\text { Widely (citrus } \\
\text { fruits) }\end{array}$ & $\begin{array}{c}\text { ROS } \downarrow \text {; pERK1/2 } \downarrow \text {; NF- } \kappa \text { B } \\
\text { p65 } \downarrow \text {, in vivo: TNF- } \alpha \downarrow ; \\
\text { IL-6 } \downarrow\end{array}$ \\
\hline Alpinetin & & rASMCs & Flavonoid & $\begin{array}{l}\text { Widely (Alpinia } \\
\text { katsumadai, } \\
\text { Amomum } \\
\text { subulatum, and } \\
\text { etc.) }\end{array}$ & $\mathrm{LDH} \downarrow ; \mathrm{NO} \downarrow$ \\
\hline $\begin{array}{l}\text { Cyanidin-3-O- } \\
\text { glucoside }\end{array}$ & & mASMCs & Flavonoid & $\begin{array}{l}\text { Hibiscus } \\
\text { sabdariffa }\end{array}$ & ROS $\downarrow ;$ NoxA1 $\downarrow ;$ pSTAT3 $\downarrow$ \\
\hline Hesperetin & & rpASMCs & Flavonoid & $\begin{array}{l}\text { Widely (lemons } \\
\text { and sweet } \\
\text { oranges) }\end{array}$ & $\begin{array}{c}\text { Block G1/S; cyclin D1 } \downarrow \text {; } \\
\text { cyclin E } \downarrow ; \text { CDK2/4 } \downarrow \text {; p38 } \\
\downarrow ; \text { p27 } \uparrow \text {; regulate } \\
\text { AKT/GSK3 } \beta \text { signaling } \\
\text { pathway }\end{array}$ \\
\hline Pinocembrin & & $\begin{array}{l}\text { rAMSCs and rat } \\
\text { aortic rings injury }\end{array}$ & Flavonoid & Propolis & ERK1/2 $\downarrow ;$ MLC2 $\downarrow$; AT1R $\downarrow$ \\
\hline Glyceollins & & hASMCs & Isoflavone & Soybean & $\begin{array}{c}\text { Arrest G1/S phase; CDK2 } \downarrow \text {; } \\
\text { cyclin D1 } \downarrow \text {; } 27 k i p 1 \uparrow ; \text { p53 } \\
\uparrow ; \text { ROS } \downarrow \text {; pPDGFr- } \beta \downarrow \text {; } \\
\text { phospholipase C } \gamma 1 \downarrow ; \text { Akt } \downarrow \text {; } \\
\text { ERK1/2 } \downarrow\end{array}$ \\
\hline
\end{tabular}


of VSMCs via a G0/G1 arrest by suppressing cyclin D1/E and CDK 2/4 [54]. Hu and colleagues found that icariin reduced the amount of ox-LDL-induced proliferation of VSMCs through suppression of PCNA expression and inactivation of ERK1/2 [55]. Puerarin, isolated from Radix puerariae, exerted inhibitory effects on high glucose-induced VSMC proliferation via interfering with $\mathrm{PKC} \beta 2 /$ Racl-dependent ROS pathways, thus resulting in attenuation of neointimal formation [56]. Alpinetin is a well-known flavonoid isolated from a variety of plants such as Alpinia katsumadai, Amomum subulatum, and Scutellaria rivularis. It may have some protective effects on VSMCs as it decreases LDH leakage and inhibits production of NO in TNF- $\alpha$-induced VSMC [57]. Hesperetin, a flavonoid, inhibits PDGFa-BB-induced pASMC proliferation via the AKT/GSK3 $\beta$ signaling pathway through upregulating p27 expression while suppressing cyclin D1/E, CDK2/4 and p38 [58]. Pinocembrin reduces the increased ERK1/2 phosphorylation that occurs in response to angiotensin II in both rat aortic rings ex vivo and VSMCs in vitro [59]. Glyceollins, which are isoflavonoids, inhibit PDGF-BB-induced hVSMC proliferation and migration by downregulating CDK2, cyclin D1, pPDGFr- $\beta$, phospholipase $\mathrm{C} \gamma 1$, Akt, and ERK1/2 and interfering with ROS generation, while upregulating p27 $7^{\mathrm{kip} 1}$ and $\mathrm{p} 53$ expression levels [60]. Morelloflavone is a biflavonoid, which has been found to block injury-induced neointimal hyperplasia via inhibition of VSMC migration and downregulation of FAK, Src, ERK and RhoA expression [61]. Some studies have demonstrated that a natural flavonoid, kaempferol, may induce miR-21. This results in downregulation of ROCK4, 5, and 7, which are critical for cytoskeletal organization and cell motility, leading to decreased cell migration [62]. Finally, green tea is beneficial for health due to its antioxidant, anticarcinogenic, anti-inflammatory, and antiradiation effects [63-65]. A large number of flavonoids, especially flavan-3-ols ("catechins"), inhibit IH in a rat balloon injury model through upregulation of TIMP-2 expression to modulate MMP activity [66]. From the above review, flavonoids are an important candidate compound type for screening natural drugs capable of inhibiting VSMC growth.

\subsection{Polyphenols as an Antioxidants Restrain VSMC Pro-} liferation and Migration to Attenuate IH. Polyphenols are distributed widely in vegetables and plants, green tea, black tea, and red wine. Recent studies have shown that they possess antioxidant, anti-inflammatory, and cardioprotective effects [67-69]. Some typical polyphenols prevent IH by restraining VSMC function including proliferation, migration, and fibrosis (Table 2). Salvianolic acid B is a typical polyphenol that is usually isolated from Salvia miltiorrhiza. It markedly reduces neointimal thickness by inducing neointimal cell apoptosis through upregulating p53 expression levels [70]. In another study, salvianolic acid B protected hAECs and neointimal formation through inhibition of LDL oxidation by reducing ROS generation [71]. Magnesium lithospermate $B$, a derivative of salvianolic acid $\mathrm{B}$, prevented diabetic atherosclerosis via the Nrf2-ARE-NQO1 transcriptional pathway [72]. Magnolol (a phenol) is a powerful antioxidant that inhibited balloon injury-induced rabbit IH by downregulating MCP-1 expression [73]. In another work, magnolol inhibited VSMC migration via the cytoskeletal remodeling pathway through inhibition of $\beta 1$-integrin expression, phosphorylation of FAK and MLC20, and activation of RhoA and Cdc42 [74]. Lithospermic acid, a polyphenol, arrested cell cycle progression at the G1 phase via downregulating expression of cyclin D1 and inhibiting ROS generation and ERK1/2 phosphorylation [75]. Moreover, lithospermic acid attenuated LPS-induced VSMC migration by inhibiting MMP-9 expression in a dose-dependent manner $(25-100 \mu \mathrm{mol} / \mathrm{L})$. Hispolon blocked balloon injury-induced neointimal hyperplasia via inhibition of VSMC proliferation. It also inhibited VSMC migration by lowering MMP-2/9 expression and increasing TIMP1/2 expression through suppression of the FAK signaling pathway [76]. Lim and colleagues were of the view that obovatol blocked the cell cycle in G1 phase by downregulating expression of cyclins and CDKs, while selectively upregulating expression of $\mathrm{p} 21^{\mathrm{Cip} 1}$, a well-known CDK inhibitor, both in vitro and in vivo [77].

Some studies have shown that curcumin (diarylheptanoid phenol) has potent antioxidant properties, which can be used for attenuating neointimal hyperplasia [78]. Curcumin has also been shown to inhibit PDGF-induced VSMC migration, proliferation, and collagen synthesis in a concentrationdependent manner [79], with a concentration range of 0.01 to $10 \mu \mathrm{mol} / \mathrm{L}$ inhibiting VSMC proliferation and migration. Curcumin-coated stents inhibited neointimal formation in the rabbit iliac artery stent model. Moreover, curcumin inhibited LPS-induced MMP-2 activity in rat VSMCs through Ras/MEK1/2 and NF- $\kappa$ B signaling [80].

Curcumin shows the ideal biological effects of inhibiting abnormal VSMC proliferation and migration without compromising VEC proliferation or delaying reendothelialization after blood vessel injury. Curcumin inhibited platelet adhesion to brain microvascular endothelial cells by decreasing expression of P-selectin, E-selectin, and GPIIb/GPIIIa in a concentration-dependent manner $(30-240 \mu \mathrm{mol} / \mathrm{L})$. Curcumin antagonized the detrimental effect of rapamycin on aortic endothelial cells in vitro, through upregulation of eNOS [81]. Hence, curcumin very selectively inhibited abnormal VSMC functions, such as PDGF-induced proliferation or migration, without impairing VECs. As a result, curcumin has been regarded as an ideal drug for attenuating atherosclerosis and restenosis. In summary, polyphenols exhibit beneficial and wide ranging biological effects relevant to prevention of $\mathrm{IH}$. Polyphenols are worthy candidate compounds to be screened as natural drugs for inhibiting VSMCs.

\subsection{Terpenes Suppress Abnormal VSMC Function against} Neointimal Formation. Terpenes are proven cell cycle inhibitors for various cell types, especially tumor cells [82, 83]. Like similar compounds with active sites for regulating VSMC mitosis and DNA synthesis, terpenes lead cell proliferation and function arrest via cell cycle blockade or apoptosis induction (Table 3). Betulinic acid, a typical terpene, has been reported to inhibit growth and proliferation of VSMCs via arresting G1/S cell cycle in a dosedependent manner [84]. A monoterpene, (S)-(-)-perillic 
TABLE 2: The structure, cells, category, source, and mechanism of typical polyphenols compounds on inhibiting VSMCs proliferation and migration.

\begin{tabular}{|c|c|c|c|c|c|}
\hline Compound name & Structure & Cells and animals & Category & Sources & Mechanism \\
\hline Salvianolic acid B & & $\begin{array}{l}\text { NeCs; HAECs and } \\
\text { cholesterol-fed } \\
\text { rabbits; } \\
\text { rTASMCs and rats } \\
\text { balloon injury }\end{array}$ & Polyphenol & $\begin{array}{c}\text { Salvia } \\
\text { miltiorrhiza }\end{array}$ & $\begin{array}{c}\text { (1) p53 } \uparrow \text {; NeCs apoptosis, (2) } \\
\text { ROS } \downarrow \text {; LDL oxidation } \downarrow \text {; lipid } \\
\text { deposition } \downarrow \text {, (3) PCNA } \downarrow \text {; } \\
\text { NQO1 } \downarrow \text {; via Nrf2-ARE-NQO1 } \\
\text { pathway }\end{array}$ \\
\hline $\begin{array}{l}\text { Caffeic acid } \\
\text { phenethyl ester } \\
\text { (CAPE) }\end{array}$ & & rASMCs & Polyphenol & $\begin{array}{l}\text { Honeybee } \\
\text { propolis }\end{array}$ & $\begin{array}{c}\text { Blocking G0/1 to S phase; } \\
\text { pp38 } \uparrow ; \mathrm{HiF} 1 \alpha \uparrow ; \mathrm{HO}-1 \uparrow\end{array}$ \\
\hline Hispolon & & rTA-A10-VSMCs & Polyphenol & Phellinus linteus & $\begin{array}{c}\text { MMP2 } \downarrow \text {;MMP9 } \downarrow \text {; TIMP-1 } \\
\text { †:TIMP- } \uparrow ; \text { pFAK } \downarrow ; \text { pERK1/2 } \\
\downarrow \text {;PI3K/AKT } \downarrow\end{array}$ \\
\hline [6]-shogaol & & rASMCs & Phenols & $\begin{array}{l}\text { Zingiber } \\
\text { officinale }\end{array}$ & $\begin{array}{c}\text { Inhibit DNA synthesis; } \\
\text { activation of (Nrf2)/HO-1 } \\
\text { pathway }\end{array}$ \\
\hline Resveratrol & & $\begin{array}{l}\text { ncTASMCs; } \\
\text { mASMCs }\end{array}$ & Polyphenol & $\begin{array}{l}\text { Widely (grapes, } \\
\text { blueberries, } \\
\text { raspberries, and } \\
\text { etc.) }\end{array}$ & $\begin{array}{c}\text { c-Src } \downarrow \text {, Racl } \downarrow \text {, cdc } 42 \downarrow \text {, IRS- } 1 \\
\downarrow, \text { MEKK } 1 \downarrow \\
\text { MEKK } 4 \downarrow \text {; p-Src; pFAK } \downarrow ; \\
\text { pAKT } \downarrow ; \text { pERK } 1 / 2 \downarrow\end{array}$ \\
\hline Lithospermic acid & & rTASMCs & Polyphenol & $\begin{array}{l}\text { Salvia } \\
\text { miltiorrhiza }\end{array}$ & $\begin{array}{l}\text { ROS } \downarrow \text {; pERK1/2 } \downarrow \text {; cyclin D } 1 \downarrow \text {; } \\
\text { arresting cell cycle progression } \\
\text { at the G1 phase; MMP9 } \downarrow\end{array}$ \\
\hline Magnolol & & $\begin{array}{l}\text { Cholesterol-fed } \\
\text { rabbits; } \\
\text { rVSMCs; rats } \\
\text { balloon injury }\end{array}$ & Polyphenol & $\begin{array}{l}\text { Magnolia } \\
\text { officinalis }\end{array}$ & $\begin{array}{c}\text { (1) MCP- } 1 \downarrow \text {, (2) Reduce } \\
\text { collagen type I deposition; } \\
\beta 1 \text {-integrin } \downarrow \text {;pFAK } \downarrow \text {;pMLC20 } \\
\downarrow \text {; RhoA } \downarrow ; \text { Cdc } 42 \downarrow\end{array}$ \\
\hline Obovatol & & $\begin{array}{l}\text { rASMCs; rats } \\
\text { balloon injury }\end{array}$ & Biphenol & $\begin{array}{c}\text { Magnolia } \\
\text { obovata }\end{array}$ & $\begin{array}{l}\text { Blocks the cell cycle in G1 } \\
\text { phase; CDKs } \downarrow ; p 21 \text { cip1 } \downarrow\end{array}$ \\
\hline Curcumin & & $\begin{array}{l}\text { rTASMCs; } \\
\text { rabbit artery } \\
\text { injury; VECs; } \\
\text { RAECs }\end{array}$ & Phenols & Curcuma longa & $\begin{array}{l}\text { (1) Inhibits PDGF Receptor } \\
\text { Binding; PDGFr } \downarrow \text {; pERK1/2 } \downarrow \text {; } \\
\text { pAkt } \downarrow,(2) \text { P-selectin } \downarrow \text {; } \\
\text { E-selectin } \downarrow \text {; GPIIb/GPIIIa } \downarrow \text {, } \\
\text { (3) MMP } \downarrow \text {; pRas } \downarrow \text {; MEK1/2 } \\
\downarrow \text {; NF- } \kappa \text { B p65 } \downarrow \text {, (4) Curcumin } \\
\text { protects aortic endothelial } \\
\text { cells; eNOS } \uparrow \text {; caveolin- } 1 \downarrow \text {; }\end{array}$ \\
\hline
\end{tabular}

acid, has been reported to decrease protein prenylation leading to DNA synthesis and inhibition of VSMCs [85]. A sesquiterpene lactone, parthenolide, arrested VSMC G0/G1 cell cycle via upregulating p21 and p27. It also increased $\mathrm{I} \kappa \mathrm{B} \alpha$ expression and reduced Cox -2 expression in a timedependent manner [86]. A special terpene, plumericin, arrested VSMCs in the G1/G0 phase of the cell cycle along with causing abrogated cyclin D1 expression, hindered Ser ${ }^{807 / 811}$-pRb protein [87], and blockade of STAT3 signaling via S-glutathionylation. Paclitaxel, a diterpenoid, has been used as an anticancer drug for decades and has been shown to prevent neointimal formation in oral administration studies [88]. Moreover, paclitaxel arrested VSMC G1/S phase by upregulating p21 and p53 in vitro [89]. Epothilone D is a paclitaxel-like microtubule-stabilizing agent that was isolated originally from the myxobacterium Sorangium cellulosum. It inhibits neointimal hyperplasia through blockade of VSMC CDK2 and pRb [90]. $\beta$-Elemene protected VECs from injury induced by $\mathrm{H}_{2} \mathrm{O}_{2}$ in vitro via downregulating MDA while upregulating T-AOC, SOD, GSH-Px, and CAT [91]. Meanwhile, $\beta$-elemene selectively inhibited VSMC proliferation/migration and inhibited neointimal formation in vivo following vascular injuries [91]. Recent studies have indicated that artemisinin effectively inhibited VSMC proliferation induced by TNF- $\alpha$ through apoptotic induction of the caspase pathway and cell cycle arrest [92, 93]. It also significantly inhibited neointimal formation in rat balloon injured carotid arteries. Therefore, terpenes are also notable candidate compounds for screening natural drugs capable of inhibiting VSMCs. 
TABLE 3: The structure, cells, category, source, and mechanism of terpenes on inhibiting VSMCs abnormal proliferation, migration, and functions.

\begin{tabular}{|c|c|c|c|c|c|}
\hline Compound name & Structure & $\begin{array}{l}\text { Cells and } \\
\text { animals }\end{array}$ & Category & Sources & Mechanism \\
\hline Betulinic Acid & & VSMCs & Terpene & $\begin{array}{l}\text { Various plant sources } \\
\text { widespread throughout } \\
\text { the tropics }\end{array}$ & $\begin{array}{c}\text { Inducing G1 Arrest and } \\
\text { Apoptosis }\end{array}$ \\
\hline Parthenolide & & rVSMCs & $\begin{array}{l}\text { Sesquiterpene } \\
\text { lactone }\end{array}$ & Tanacetum parthenium & $\begin{array}{l}\text { G0/G1 cell cycle arrest; p21 } \text {; } \\
\text { p27 } \uparrow ; \mathrm{I} \kappa \mathrm{B} \alpha \uparrow ; \text { Cox- } 2 \downarrow\end{array}$ \\
\hline Plumericin & & rAVSMCs & $\begin{array}{l}\text { Iridoid } \\
\text { (Terpene) }\end{array}$ & Himatanthus sucuuba & $\begin{array}{c}\text { Block STAT3 signaling; arrest } \\
\text { VSMCs in the G1/G0-phase; } \\
\text { cyclin D1 } \downarrow \text {; pRb } \downarrow\end{array}$ \\
\hline Paclitaxel & & $\begin{array}{c}\text { Rat balloon } \\
\text { injury; } \\
\text { hCASMCs } \\
\text { (CC-2583) } \\
\text { and VSMCs } \\
\text { (CC-2571); } \\
\text { rTASMCs } \\
\text { and VECs }\end{array}$ & Diterpenoid & Taxus cuspidata & $\begin{array}{c}\text { (1) prevent neointimal } \\
\text { formation via oral } \\
\text { administration, (2) arrest G1/S } \\
\text { phase; } \mathrm{p} 21 \uparrow ; \mathrm{p} 53 \uparrow\end{array}$ \\
\hline Epothilone D & & $\begin{array}{l}\text { rTASMCs; } \\
\text { carotid artery } \\
\quad \text { injury }\end{array}$ & Diterpenoid & Sorangium cellulosum & $\mathrm{CDK} 2 \downarrow ; \mathrm{pRb} \downarrow$ \\
\hline$\beta$-elemene & & $\begin{array}{l}\text { hUVECs and } \\
\text { VSMCs } \\
\text { (A7r5); rat } \\
\text { balloon } \\
\text { injury }\end{array}$ & Terpene & Curcuma wenyujin & $\begin{array}{c}\text { Antioxidant; Casp 3/7/9 } \uparrow ; \\
\text { Migration } \downarrow\end{array}$ \\
\hline Artemisinin & & $\begin{array}{l}\text { rVSMCs and } \\
\text { rat balloon } \\
\text { injury; } \\
\text { rTASMCs }\end{array}$ & $\begin{array}{l}\text { Sesquiterpene } \\
\text { lactone }\end{array}$ & Artemisia annua & $\begin{array}{c}\text { (1) arrest G0/G1 phase; cyclin } \\
\mathrm{D} 1 / \mathrm{E} \downarrow \text {; CDK2/4 } \downarrow \text {; caspase } 3 / 9 \\
\uparrow ; \mathrm{Bax} \uparrow ; \mathrm{Bcl}-2 \downarrow \text {, (2) PCNA } \downarrow \text {; } \\
\text { caspase } 3 \uparrow ; \mathrm{Bax} \uparrow ; \mathrm{Bax} / \mathrm{Bcl}-2 \\
\text { ratio } \uparrow\end{array}$ \\
\hline (S)-(-)-Perillic acid & & rASMCs & Monoterpene & Widely & Protein prenylation $\downarrow$ \\
\hline
\end{tabular}

5.4. Alkaloids Exhibit Antiproliferation Biological Effect on VSMCs. Alkaloids are a group of naturally occurring chemical compounds that mostly contain basic nitrogen atoms. Alkaloids have diverse biological effects including those against tumors, hypertension, and pain. For vascular IH, some studies indicate that alkaloids hinder cell cycle progress, decrease ROS production, and inhibit VSMC migration (Table 4). A classic alkaloid, piperine, selectively inhibits VSMC proliferation with an IC50 of $11.8 \mu \mathrm{mol} / \mathrm{L}$ without influencing VEC growth [94]. Coptisine was isolated from Coptis chinensis and suppresses VSMC proliferation selectively at lower concentrations with a $\mathrm{GI}_{50}$ of $3.3 \mu \mathrm{mol} / \mathrm{L}$ (1.2 $\mu \mathrm{g} / \mathrm{mL})$ [95]. Vinpocetine, a potential derivative of vincamine, inhibits high glucose-induced proliferation of VSMCs by preventing ROS generation and affecting MAPK, PI3K/Akt, and NF-KB signaling, Wang, Wen, Peng, Li, Zhuang, Lu, Liu, Li, Li, and $\mathrm{Xu}$ [96]. Vinpocetine arrested G1/S phase of the cell cycle by downregulating cyclin D1 and pERK1/2. Alongside these effects, vinpocetine also inhibited VSMC migration and ROS production [97]. A quinazolinone alkaloid, halofuginone, selectively inhibited cell proliferation, ECM deposition, and type I collagen synthesis in VSMCs versus VECs, which attenuated injury-induced IH [98]. Carbazole or murrayafoline A inhibited PDGF-BB induced abnormal proliferation of VSMCs by downregulating cyclin $\mathrm{D} 1 / \mathrm{E}, \mathrm{CDK} 2 / 4$, and PCNA and phosphorylation of Rb [99]. 
TABLE 4: The structure, cells, category, source, and mechanism of alkaloids on inhibiting VSMCs abnormal proliferation, migration, and functions.

\begin{tabular}{|c|c|c|c|c|c|}
\hline Compound name & Structure & Cells and animals & Category & Sources & Mechanism \\
\hline Piperine & & rASMCs & Alkaloid & Piper nigrum & Selectively inhibit VSMCs \\
\hline Coptisine & & rVSMCs & Alkaloid & Coptis chinensis & Arrest G1/S phase \\
\hline Vinpocetine & & $\begin{array}{l}\text { rVSMCs and rat } \\
\text { balloon injury; } \\
\text { rASMCs and mice } \\
\text { carotid artery } \\
\text { ligation injury }\end{array}$ & $\begin{array}{l}\text { Alkaloid } \\
\text { vincamine }\end{array}$ & $\begin{array}{l}\text { Lesser periwinkle } \\
\text { plants }\end{array}$ & $\begin{array}{c}\text { (1) ROS } \downarrow \text {; apoptosis } \downarrow \text {; pAkt } \downarrow \text {; } \\
\text { pJNK1/2 } \downarrow ; \text { I } \kappa \alpha \downarrow \text { B } \text {; PCNA } \downarrow \text {; } \\
\text { cyclin D } \downarrow \text {; Bcl-2 } \downarrow \text {, (2) Arrest } \\
\text { G1/S phase; cyclin D1 } \downarrow \text {; } \\
\text { p27 Kip1 } \uparrow ; \text { inhibit migration; } \\
\text { pERK1/2 } \downarrow \text {; ROS } \downarrow\end{array}$ \\
\hline Halofuginone & & bASMCs & $\begin{array}{l}\text { Quinazolinone } \\
\text { alkaloid }\end{array}$ & Dichroa febrifuga & $\begin{array}{c}\text { ECM synthesis and deposition } \\
\qquad \downarrow \text {; Col I } \downarrow\end{array}$ \\
\hline Murrayafoline A & & rASMCs & $\begin{array}{l}\text { Carbazole } \\
\text { alkaloid }\end{array}$ & $\begin{array}{l}\text { Glycosmis } \\
\text { stenocarpa } \\
\text { Guillaumin }\end{array}$ & $\begin{array}{l}\text { Arrest G1/S phase; cyclin D1/E } \\
\downarrow ; \text { CDK } 2 / 4 \downarrow ; \mathrm{PCNA} \downarrow ; \mathrm{pRb} \downarrow\end{array}$ \\
\hline
\end{tabular}

Review of these recent studies on the effects of alkaloids provides hope for identification of useful drugs capable of inhibiting VSMC growth and preventing IH.

\subsection{Other Promising Natural Compounds for Preventing} Intima Hyperplasia. As shown in Table 5, emodin is a typical anthraquinone compound beneficial for prevention of atherosclerosis due to its effects against inflammation, proliferation, and migration and its ability to induce apoptosis in VSMCs [100]. Moreover, emodin arrested growth and induced apoptosis and autophagy via enhanced ROS production and upregulation of p53 expression [101]. Emodin inhibited VSMC proliferation induced by angiotensin II through downregulation of PCNA and c-myc expression [102]. Moreover, emodin showed anti-inflammatory effects by inhibiting Hcy-induced CRP generation, a key inflammatory molecule in atherogenesis in VSMCs [103]. Emodin has also been shown to inhibit TNF- $\alpha$-induced hASMC proliferation via caspase signaling and a mitochondrial-dependent apoptotic pathway by downregulating $\mathrm{Bcl}-2$ and upregulating Bax expression [104]. Additionally, emodin reduced TNF- $\alpha$ induced migration of VSMCs by suppressing NF- $\kappa \mathrm{B}$ activation and MMP2/9 expression levels [105]. Our recent study demonstrated that emodin efficiently and concentrationdependently $(0.05$ to $5 \mu \mathrm{mol} / \mathrm{L})$ inhibited hVSMC proliferation more than hVEC proliferation in vitro, with less influence on reendothelialization of VECs in rat carotid artery balloon injury [106].

Methyl-protodioscin is a steroidal saponin that has been reported to inhibit neointimal formation by restraining VSMC proliferation and migration through downregulation of ADAM15, FAK, ERK, PI3K, Akt, and MMP-2/9 expression levels [107]. Salvia miltiorrhiza has been used to prevent cardiovascular diseases in traditional Chinese medicine over the millennia. Tanshinone-IIA is a principal active component of Salvia miltiorrhiza that suppresses abnormal VSMC proliferation by cell cycle arrest at G0/G1 phase and inhibits phosphorylation of ERK1/2 and c-fos expression [108]. It has been reported that ajoene $(1-50 \mu \mathrm{nol} / \mathrm{L})$ interfered with progression of the G1 phase in the cell cycle and restrained rat VSMC proliferation via inhibiting protein prenylation [109]. Gastrodin influenced the S phase entry of VSMCs and stabilized $\mathrm{p} 27^{\mathrm{KIP} 1}$ expression. It also inhibited VSMC proliferation and attenuated neointimal hyperplasia by suppressing phosphorylation of ERK1/2, p38 MAPK, Akt, and GSK3 $\beta$ [110]. Genipin has been reported to inhibit TNF$\alpha$ induced VSMC proliferation and migration in a dosedependent manner by upregulating HO-1 expression, preventing ERK/MAPK and Akt phosphorylation, and additionally blocking generation of ROS [111]. Ginsenoside Rg1 is one of the main active components of Panax ginseng and is said to arrest G1/S phase in VSMCs by interfering with GRKs, PKC, and N-ras while upregulating p21 expression [112]. Vascular IH is significantly decreased when carotid artery balloon injured rats are intraperitoneally injected with ginsenoside Rg1 for 14 days [113]. Moreover, ginsenoside Rg1 significantly inhibited TNF- $\alpha$-induced hASMC proliferation dose-dependently through downregulating cyclin D1, inactivating ERK1/2 and $\mathrm{PKB}$, and upregulating expression of p53, $\mathrm{p} 21^{\mathrm{WAF} / \mathrm{CIP} 1}$, and $\mathrm{p} 27^{\mathrm{KIP} 1}$ [114]. A coumarin called ostruthin is a major bioactive constituent of Peucedanum ostruthium and inhibited serum (10\%)-induced VSMC proliferation in a dose-dependent manner [115].

Most foods contain various biologically active constituents that act to prevent and cure neointimal hyperplasia by inhibiting abnormal VSMC proliferation and migration. A well-known carotenoid, lycopene, is abundant in tomatoes and its products and has been reported to inhibit neointimal hyperplasia in a rabbit restenosis model. It does this by 
TABLE 5: The structure, cells, category, source, and mechanism of promising compounds on suppressing VSMCs.

\begin{tabular}{|c|c|c|c|c|c|}
\hline $\begin{array}{l}\text { Compound } \\
\text { name }\end{array}$ & Structure & Cells and animals & Category & Sources & Mechanism \\
\hline Bilirubin & & $\begin{array}{l}\text { rVSMCs and } \\
\text { mVSMCs; rat } \\
\text { balloon injury }\end{array}$ & $\begin{array}{c}\text { Ferric } \\
\text { porphyrins }\end{array}$ & Heme & $\begin{array}{c}\text { Inhibit MAPK signaling } \\
\text { pathway; CDK2 } \downarrow \text {; Cyclin } \\
\text { A/D1/E } \downarrow ; \text { pRb } \downarrow ; \text { YY } 1 \downarrow ; \text { p38 } \downarrow\end{array}$ \\
\hline capsaicin & & rASMCs & Capsaicinoids & Chili peppers & Inhibit DNA synthesis \\
\hline Emodin & & $\begin{array}{l}\text { hUVSMCs; } \\
\text { rTASMCs; } \\
\text { hASMCs; rat } \\
\text { balloon injury }\end{array}$ & Anthraquinone & Rheum officinale & $\begin{array}{c}\text { (1) Arrest cell cycle, induce } \\
\text { apoptosis and autophagy; ROS } \\
\uparrow \text {; p53 } \uparrow,(2) \text { PCNA } \downarrow \text {; c-myc } \downarrow \text {, } \\
\text { (3) CRP } \downarrow \text {; ROS } \downarrow \text {; pERK1/2 } \downarrow \text {; } \\
\text { p38 } \downarrow \text {; PPAR } \uparrow \uparrow,(4) \text { Induce } \\
\text { apoptosis; Bcl- } 2 \downarrow \text {; Bax } \uparrow,(5) \\
\text { MMP } 2 / 9 \downarrow \text {; NF- } \kappa \text { B activation } \\
\downarrow\end{array}$ \\
\hline Rhein & & hASMCs & Anthraquinone & Rheum palmatum & $\begin{array}{c}\text { Col I/III } \downarrow ; \\
\text { Wnt4/Dvl-1/ } \beta \text {-catenin } \downarrow ; \\
\text { miR-126 }\end{array}$ \\
\hline Ajoene & & rASMCs & $\begin{array}{l}\text { Organosulphur } \\
\text { compound }\end{array}$ & Allium sativum & $\begin{array}{l}\text { Inhibit protein prenylation } \\
\text { and cholesterol biosynthesis }\end{array}$ \\
\hline Gastrodin & & $\begin{array}{l}\text { rASMCs, mice } \\
\text { artery injury }\end{array}$ & Glucoside & Gastrodia elata B1 & $\begin{array}{c}\text { Block S-phase; stabilised } \\
\text { p27Kip1; PCNA } \downarrow \text {; pERK1/2 } \downarrow \text {; } \\
\text { pp38 } \downarrow \text {; pAkt } \downarrow \text {; pGSK3 } \beta \downarrow\end{array}$ \\
\hline Genipin & & rTASMCs & Aglycon & $\begin{array}{l}\text { Gardenia } \\
\text { jasminoides }\end{array}$ & $\begin{array}{c}\mathrm{HO}-1 \uparrow ; \mathrm{pERK} / \mathrm{MAPK} \downarrow ; \mathrm{pAkt} \\
\downarrow \\
; \text { ROS } \downarrow\end{array}$ \\
\hline Ginsenoside Rg1 & & $\begin{array}{l}\text { hASMCs; rat } \\
\text { balloon injury }\end{array}$ & $\begin{array}{l}\text { Steroid } \\
\text { glycosides }\end{array}$ & Panax ginseng & $\begin{array}{c}\text { (1) PCNA } \downarrow \text {; pERK2 } \downarrow \text {; c-fos } \downarrow \text {; } \\
\text { MKP-1 } \uparrow ;(2) \text { Arrest G1/S } \\
\text { phase; GRKs } \downarrow \text {; PKC } \downarrow ; \text { N-ras } \\
\downarrow \text {; p21 } \uparrow,(3) \text { Cyclin D } 1 \downarrow \text {; } 53 \uparrow ; \\
\text { p21WAF/CIP1 } \uparrow ; \text { p } 27 \text { KIP1 } \uparrow ; \\
\text { inactivate PKB and ERK1/2 }\end{array}$ \\
\hline Ostruthin & & rTASMCs & Coumarins & $\begin{array}{l}\text { Peucedanum } \\
\text { ostruthium }\end{array}$ & Inhibit DNA synthesis \\
\hline Lycopene & & $\begin{array}{l}\text { Rabbit artery } \\
\text { injury }\end{array}$ & Carotenoid & $\begin{array}{l}\text { Widely (tomatoes, } \\
\text { red carrots,) }\end{array}$ & $\begin{array}{c}\text { TG } \downarrow \text {; TC } \downarrow \text {; LDL-C } \downarrow \text {; HDL-C } \\
\uparrow ; \text { SOD } \uparrow ; \text { T-AOC } \uparrow ; \text { MDA } \downarrow \text {; } \\
\text { PCNA } \downarrow ; \text { pERK1/2 } \downarrow \text {; Nox } 1 \downarrow ; \\
\text { p22 }{ }^{\text {phox }} \downarrow ; \text { HMG-CoA } \downarrow ; \\
\text { ABCA } 1 \uparrow\end{array}$ \\
\hline $\begin{array}{l}\text { Methyl } \\
\text { Protodioscin }\end{array}$ & & $\begin{array}{l}\text { A7r5 VSMCs; rat } \\
\text { balloon injury }\end{array}$ & $\begin{array}{l}\text { Steroidal } \\
\text { saponin }\end{array}$ & Dioscorea collettii & $\begin{array}{c}\text { Arrest G1/S phase; ADAM15 } \\
\downarrow \text {; MMP2/9 } \downarrow \text {; FAK } \downarrow \text {; ERK } \downarrow \text {; } \\
\text { PI3K } \downarrow \text {; Akt } \downarrow\end{array}$ \\
\hline Tanshinone IIA & & $\begin{array}{l}\text { rASMCs; rat } \\
\text { balloon injury }\end{array}$ & Phenolic acids & Salvia miltiorrhiza & $\begin{array}{l}\text { Block cell cycle in G0/G1 } \\
\text { phase; pERK1/2 } \downarrow \text {; c-fos } \downarrow\end{array}$ \\
\hline Sulforaphane & & $\begin{array}{l}\text { rASMCs; rat } \\
\text { balloon injury }\end{array}$ & $\begin{array}{l}\text { Organosulfur } \\
\text { compounds }\end{array}$ & $\begin{array}{l}\text { Widely (cruciferous } \\
\text { vegetables such as } \\
\text { broccoli, Brussels } \\
\text { sprouts, and } \\
\text { cabbages) }\end{array}$ & $\begin{array}{c}\mathrm{p} 21 \uparrow ; \mathrm{p} 53 \uparrow ; \mathrm{CDK} 2 \downarrow ; \text { Cyclin E } \\
\downarrow ; \text { PCNA } \downarrow\end{array}$ \\
\hline
\end{tabular}


TABLE 6: The selected potential targets of the compounds.

\begin{tabular}{|c|c|c|c|c|c|c|}
\hline \multirow[b]{2}{*}{ Seq } & Idarubicin & Halofuginone & Piperine & $\beta$-elemene & Curcumin & Coptisine \\
\hline & \multicolumn{6}{|c|}{ Predicted target names (most related top 15) } \\
\hline 1 & MAPT & $\mathrm{BCHE}$ & MAOA & MAPT & MAPT & CHRM4 \\
\hline 2 & MBNL1 & $\mathrm{ACHE}$ & MAOB & TDP1 & TLR9 & CHRM1 \\
\hline 3 & MBNL2 & MAPK8 & SIGMAR1 & CXCR3 & TDP1 & CHRM2 \\
\hline 4 & MBNL3 & MAPK9 & MBNL1 & SLC6A2 & Unknown & CHRM5 \\
\hline 5 & MMP2 & MAPK10 & MBNL2 & SLC6A3 & MBNL1 & CHRM3 \\
\hline 6 & MMP9 & MAPK11 & MBNL3 & LDLR & MBNL2 & BCHE \\
\hline 7 & APP & MAPK14 & MAPT & VLDLR & MBNL3 & ADRA2A \\
\hline 8 & SNCA & HTR1A & DRD2 & LRP8 & GLO1 & CYP2D6 \\
\hline 9 & APLP2 & HTR1B & DRD3 & HSD11B1 & AKT1 & ADRA2B \\
\hline 10 & SNCG & MAPT & HDAC3 & BACE1 & AKT2 & ADRA2C \\
\hline 11 & SNCB & HTR2A & HDAC1 & HSD11B1L & AKT3 & ACHE \\
\hline 12 & TDP1 & DRD2 & HDAC2 & BACE2 & HSD17B3 & HTR2A \\
\hline 13 & EGFR & DRD1 & DYRK1A & HTR1A & HSD17B12 & HTR2C \\
\hline 14 & ERBB2 & OPRM1 & HDAC6 & HTR1D & CRYZ & HTR2B \\
\hline 15 & ERBB3 & OPRD1 & CTSL1 & HTR1B & $\mathrm{APP}$ & SIGMAR1 \\
\hline
\end{tabular}

regulation of blood lipid concentrations and suppression of oxidative stress [116]. Sulforaphane, an organosulfur compound, mostly found in cruciferous vegetables significantly inhibited PDGF-BB-induced VSMC proliferation by upregulating p21 and p53 expression, while CDK2, cyclin E, and PCNA expression was suppressed [117].

\section{Selective Inhibition of VSMCs versus VECs Shows Significant}

Although many natural products inhibit VSMC function, most anti-smooth muscle proliferation drugs such as rapamycin (in-stent coating) also inhibit VEC proliferation and delay reendothelialization. This nonspecific cytotoxicity leads to restenosis and final graft or stent implantation failure. When screening for selective natural drugs that inhibit smooth muscle cell proliferation and migration, it is necessary to combine computer-aided design, bioinformatics, and a high-throughput screening platform. In this review, we selected certain drugs including chemosynthetic (idarubicin) and some natural ( $\beta$-elemene, coptisine, halofuginone, piperine, and curcumin) compounds that possess specificity for suppressing proliferation of VSMCs over VECs. The chemical structure of the natural compounds has no typical similarity and cannot be analyzed using structural-activity relationships of molecular-protein binding sites. However, an online tool "Swiss Target Prediction" was used to predict potential targets of these compounds [118]. Most of the predicted targets of these drugs were membrane receptors, enzymes, kinases, proteases, or transporter proteins (Table 6). The analyses showed that microtubule-associated protein TAU (MAPT) is the most frequent protein target among them (Figure 4). This stabilizes microtubules and influences transportation of cellular secretory proteins. Moreover, MAPT has been reported to accelerate cancer cell growth [119], while its inactivation through gene knockdown suppressed cell proliferation [120].
Therefore, it is speculated that the diverse affinity of a natural drug to different functional protein targets may be one of the key factors for different selectivity profiles on VSMCs or VECs. Common targets like MAPT could be used as one of the important indicators in screening selective inhibitory drugs in future studies.

\section{Conclusion}

This review highlighted the originating four cells that may contribute to $\mathrm{IH}$ and then focused on VSMCs due to their involvement in intima formation as a consequence of abnormal proliferation, migration, and physiology. It further summarized typical signaling pathways such as MAPKs, PI3K/Akt, JAK-STAT, FAK, and NF- $\kappa$ B and their involvement in the abnormal activities of VSMCs. Based on these the above cell origins and pathways, we organized and classified different natural isolates including phenols, flavonoids, terpenes, and alkaloids that have suppressing effects on VSMCs. In addition, many natural drugs not only induce apoptosis and arrest cell cycle in VSMCs, but also impair VECs leading to vascular restenosis and failure of blood vessel remodeling. Thus, it is crucial to screen desirable drugs from natural sources that preferentially inhibit VSMCs versus VECs to prevent $\mathrm{IH}$ in the early stages, restenosis following graft implantation, and even atherosclerotic diseases.
Abbreviations
IH: Intimal hyperplasia
EndMT: Endothelial-to-mesenchymal transition
rASMCs: Rat aortic smooth muscle cells
rTASMCs: Rat thoracic aortic smooth muscle cells
VSMCs: Vascular smooth muscle cells
CA: $\quad$ Carotid artery
RAECs: Rat aortic endothelial cells 

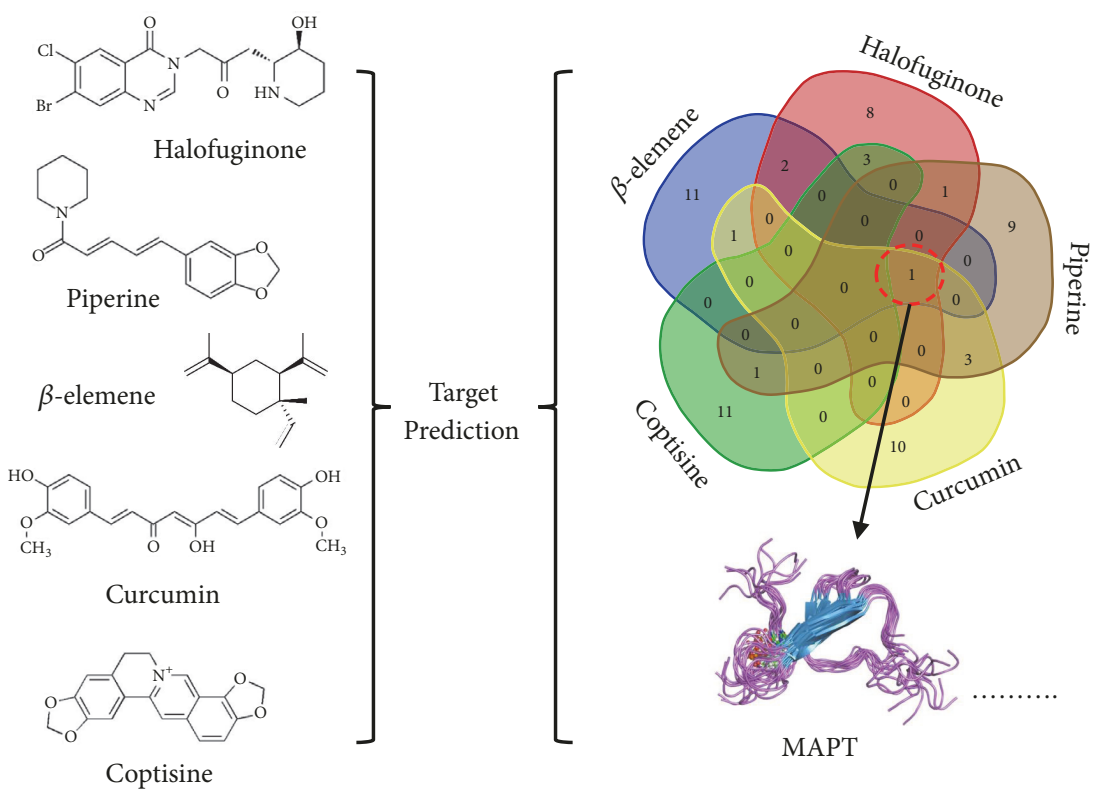

FIGURE 4: The compounds potential target: MAPT which is a common target.

HAECs:

VECs:

hUVECs:

hUVSMCs:

NeCs:

rTA-A10-VSMC

ncTASMCs:

mASMCs:

hPASMCs:

rPASMCs:

hCASMCs:

bASMCs:

MYH11:

SM22 $\alpha /$ tagln:

ACTA2:

ECM:

TNF- $\alpha$ :

PDGF:

ERK:

MMP:

MAPK:

JNK:

PCNA:

PI3K:

AKT:

CDK:

JAK:

STAT:
Human aortic endothelial cells

Vascular endothelial cells

Human umbilical vein endothelial cells

Human umbilical vein smooth muscle

cells

Neointimal cells

muscle cells

Newborn calf thoracic aorta smooth muscle cells

Mice aortic smooth muscle cells

Human pulmonary artery smooth muscle cells

Rat pulmonary artery smooth muscle cells

Human coronary artery smooth muscle cells

Bovine aortic smooth muscle cells

Smooth muscle cell myosin heavy chain

SMC lineage-restricted protein

Alpha smooth muscle actin

Extracellular matrix

Tumor necrosis factor- $\alpha$

Platelet-derived growth factor

Extracellular signal-regulated kinase

Matrix metalloproteinase

Mitogen-activated protein kinase

c-Jun $\mathrm{N}$ terminal kinase

Proliferating cell nuclear antigen

Phosphatidylinositol-4,5-bisphosphate

3-kinase

Serine/threonine kinase 1

Cyclin-dependent kinase

Janus kinase

Signal transducer and activator of transcription protein
FAK: $\quad$ Focal adhesion kinase

NF- $\kappa$ B: $\quad$ Nuclear factor kappa B

LDL: $\quad$ Low-density lipoprotein

ROS: $\quad$ Reactive oxygen specie

IL-1 $\beta$ : $\quad$ Interleukin $1-\beta$

LPS: $\quad$ Lipopolysaccharide

Nox: NADPH oxidase

TIMP: $\quad$ Tissue inhibitors of metalloproteinase

NOS: $\quad$ Nitric oxide synthase

IC50: Half maximal inhibitory concentration

miR-21: MicroRNA-21

NO: $\quad$ Nitric oxide

LDH: Lactate dehydrogenase

eNOS: $\quad$ Nitric oxide synthase

pPDGFr- $\beta$ : $\beta$-type platelet-derived growth factor receptor

ROCK: Rho-associated protein kinase

$\mathrm{Rb}$ : Retinoblastoma tumor suppressor protein family.

\section{Conflicts of Interest}

The authors declare that they have no conflicts of interest.

\section{Authors' Contributions}

Kang $\mathrm{Xu}$, Mohanad $\mathrm{Kh} \mathrm{Al}$-ani, and Xin Pan designed the project, performed the experiments, collected the data, and wrote the manuscript. Qingjia Chi analyzed the data and wrote and revised the manuscript. Nianguo Dong and Xuefeng Qiu designed the project, gave financial support, and wrote and revised the manuscript. All authors read and approved the final manuscript. 


\section{Acknowledgments}

This work was supported by National Key R\&D Plan (2018YFA0108700, 2016YFA0101100), National Natural Science Foundation of China (81873471, 11602181, 30371414, 30571839, 30872540, 31330029, 81170214, 81270297, 11602181), the Fundamental Research Funds for the Central Universities, South-Central University for Nationalities (Grant Number: CZQ18019), the China Postdoctoral Science Foundation (Grant Number: 2018M630867), the Visiting Scholar Foundation of Key Laboratory of Biorheological Science and Technology (Chongqing University), Ministry of Education (Grant Number: CQKLBST-2018-009 and CQKLBST-2018006), and the Fundamental Research Funds for the Central Universities (WUT: 2016IVB063, 2018IB005). The authors thank Dr. Peng Zhu for help in organizing and writing the manuscript.

\section{References}

[1] V. M. Subbotin, "Analysis of arterial intimal hyperplasia: Review and hypothesis," Theoretical Biology and Medical Modelling, vol. 4, article no. 41, 2007.

[2] M. R. Bennett, S. Sinha, and G. K. Owens, "Vascular smooth muscle cells in atherosclerosis," Circulation Research, vol. 118, no. 4, pp. 692-702, 2016.

[3] Y. Hu and Q. Xu, "Adventitial biology: differentiation and function," Arteriosclerosis, Thrombosis, and Vascular Biology, vol. 31, no. 7, pp. 1523-1529, 2011.

[4] N. Kipshidze, G. Dangas, M. Tsapenko et al., "Role of the endothelium in modulating neointimal formation: vasculoprotective approaches to attenuate restenosis after percutaneous coronary interventions," Journal of the American College of Cardiology, vol. 44, no. 4, pp. 733-739, 2004.

[5] D. Skowasch, A. Jabs, R. Andrié, S. Dinkelbach, B. Lüderitz, and G. Bauriedel, "Presence of bone-marrow- and neural-crestderived cells in intimal hyperplasia at the time of clinical instent restenosis," Cardiovascular Research, vol. 60, no. 3, pp. 684-691, 2003.

[6] J.-B. Michel, Z. Li, and P. Lacolley, "Smooth muscle cells and vascular diseases," Cardiovascular Research, vol. 95, no. 2, pp. 135-137, 2012.

[7] P. Lacolley, V. Regnault, A. Nicoletti, Z. Li, and J.-B. Michel, “The vascular smooth muscle cell in arterial pathology: a cell that can take on multiple roles," Cardiovascular Research, vol. 95, no. 2, pp. 194-204, 2012.

[8] H. Lee Ching, H. Lin Ruey, S. H. Liu, and S. Y. Lin-Shiau, "Mutual interactions among ingredients of betel quid in inducing genotoxicity on Chinese hamster ovary cells," Mutation Research - Genetic Toxicology, vol. 367, no. 2, pp. 99-104, 1996.

[9] K. Yoshino, Y. Hara, M. Sano, and I. Tomita, "Antioxidative effects of black tea theaflavins and thearubigin on lipid peroxidation of liver homogenates induced by tert-butyl hydroperoxide," Biological \& Pharmaceutical Bulletin, vol. 17, no. 1, pp. 146-149, 1994.

[10] M. Sano, M. Suzuki, T. Miyase, K. Yoshino, and M. MaedaYamamoto, "Novel antiallergic catechin derivatives isolated from oolong tea," Journal of Agricultural and Food Chemistry, vol. 47, no. 5, pp. 1906-1910, 1999.

[11] K. Koga, M. Hisamura, T. Kanetaka, K. Yoshino, Y. Matsuo, and T. Tanaka, "Proanthocyanidin Oligomers Isolated from Salacia reticulata leaves potently Inhibit Pancreatic Lipase Activity," Journal of Food Science, vol. 78, no. 1, pp. H105-H111, 2013.

[12] M. Sovak, "Grape extract, resveratrol, and its analogs: A review," Journal of Medicinal Food, vol. 4, no. 2, pp. 93-105, 2001.

[13] A. Luximon-Ramma, V. S. Neergheen, T. Bahorun et al., "Assessment of the polyphenolic composition of the organic extracts of Mauritian black teas: A potential contributor to their antioxidant functions," BioFactors, vol. 27, no. 1-4, pp. 79-91, 2006.

[14] K. Goszcz, S. J. Deakin, G. G. Duthie, D. Stewart, S. J. Leslie, and I. L. Megson, "Antioxidants in cardiovascular therapy: panacea or false hope?" Frontiers in Cardiovascular Medicine, vol. 2, article 29, pp. 1-22, 2015.

[15] O. Araim, J. Ballantyne, A. L. Waterhouse, and B. E. Sumpio, "Inhibition of vascular smooth muscle cell proliferation with red wine and red wine polyphenols," Journal of Vascular Surgery, vol. 35, no. 6, pp. 1226-1232, 2002.

[16] J.-R. Du, X. Li, R. Zhang, and Z.-M. Qian, “Tanshinone inhibits intimal hyperplasia in the ligated carotid artery in mice," Journal of Ethnopharmacology, vol. 98, no. 3, pp. 319-322, 2005.

[17] F. Li, X. Shang, X. Du, and S. Chen, "Rapamycin Treatment Attenuates Angiotensin II -induced Abdominal Aortic Aneurysm Formation via VSMC Phenotypic Modulation and Down-regulation of ERK1/2 Activity," Current Medical Science, vol. 38, no. 1, pp. 93-100, 2018.

[18] A. Lindqvist, B.-O. Nilsson, E. Ekblad, and P. Hellstrand, "Platelet-derived growth factor receptors expressed in response to injury of differentiated vascular smooth muscle in vitro: Effects on ca2+ and growth signals," Acta Physiologica Scandinavica, vol. 173, no. 2, pp. 175-184, 2001.

[19] L. Cao, D. Pan, D. Li et al., "Relation between antiatherosclerotic effects of IRAK4 and modulation of vascular smooth muscle cell phenotype in diabetic rats," American Journal of Translational Research, vol. 8, no. 2, pp. 899-910, 2016.

[20] G. Sánchez-Duffhues, A. García de Vinuesa, and P. ten Dijke, "Endothelial-to-mesenchymal transition in cardiovascular diseases: Developmental signaling pathways gone awry," Developmental Dynamics, vol. 247, no. 3, pp. 492-508, 2018.

[21] T. Suzuki, E. J. Carrier, M. H. Talati et al., "Isolation and characterization of endothelial-to-mesenchymal transition cells in pulmonary arterial hypertension," American Journal of Physiology-Lung Cellular and Molecular Physiology, vol. 314, no. 1, pp. L118-L126, 2018.

[22] A. Li, W. Peng, X. Xia, R. Li, Y. Wang, and D. Wei, "Endothelial-to-Mesenchymal Transition: A Potential Mechanism for Atherosclerosis Plaque Progression and Destabilization," DNA and Cell Biology, vol. 36, no. 11, pp. 883-891, 2017.

[23] J. A. Moonen, E. S. Lee, M. Schmidt et al., "Endothelialto-mesenchymal transition contributes to fibro-proliferative vascular disease and is modulated by fluid shear stress," Cardiovascular Research, vol. 108, no. 3, pp. 377-386, 2015.

[24] A. Saiura, M. Sata, Y. Hirata, R. Nagai, and M. Makuuchi, "Circulating smooth muscle progenitor cells contribute to atherosclerosis," Nature Medicine, vol. 7, no. 4, pp. 382-383, 2001.

[25] K. Tanaka, M. Sata, T. Natori et al., "Circulating progenitor cells contribute to neointimal formation in nonirradiated chimeric mice," The FASEB Journal, vol. 22, no. 2, pp. 428-436, 2008.

[26] P. Li, C. Pan, M. Sheu et al., "Deep Sea Water Prevents Balloon Angioplasty-Induced Hyperplasia through MMP-2: An In Vitro and In Vivo Study," PLoS ONE, vol. 9, no. 5, p. e96927, 2014. 
[27] G. Pearson, F. Robinson, T. B. Gibson et al., "Mitogen-activated protein (MAP) kinase pathways: regulation and physiological functions," Endocrine Reviews, vol. 22, no. 2, pp. 153-183, 2001.

[28] V. Asati, D. K. Mahapatra, and S. K. Bharti, "PI3K/Akt/mTOR and Ras/Raf/MEK/ERK signaling pathways inhibitors as anticancer agents: Structural and pharmacological perspectives," European Journal of Medicinal Chemistry, vol. 109, pp. 314-341, 2016.

[29] J. Zhong, "RAS and downstream RAF-MEK and PI3K-AKT signaling in neuronal development, function and dysfunction," biological chemistry, vol. 397, no. 3, pp. 215-222, 2016.

[30] L. Romorini, X. Garate, G. Neiman et al., "AKT/GSK3 $\beta$ signaling pathway is critically involved in human pluripotent stem cell survival," Scientific Reports, vol. 6, no. 1, 2016.

[31] T. Shimura, S. Kakuda, Y. Ochiai, Y. Kuwahara, Y. Takai, and M. Fukumoto, "Targeting the AKT/GSK3 $\beta /$ Cyclin D1/Cdk4 Survival Signaling Pathway for Eradication of Tumor Radioresistance Acquired by Fractionated Radiotherapy," International Journal of Radiation Oncology • Biology • Physics, vol. 80, no. 2, pp. 540-548, 2011.

[32] H. Kiu and S. E. Nicholson, "Biology and significance of the JAK/STAT signalling pathways," Growth Factors, vol. 30, no. 2, pp. 88-106, 2012.

[33] E. N. Fish and L. C. Platanias, "Interferon receptor signaling in malignancy: A network of cellular pathways defining biological outcomes," Molecular Cancer Research, vol. 12, no. 12, pp. 16911703, 2014.

[34] J.-L. Guan and D. Shalloway, "Regulation of focal adhesionassociated protein tyrosine kinase by both cellular adhesion and oncogenic transformation," Nature, vol. 358, no. 6388, pp. 690692, 1992.

[35] M. D. Schaller, C. A. Borgman, B. S. Cobb, R. R. Vines, A. B. Reynolds, and Parsons. J. T., "pp125FAK a structurally distinctive protein-tyrosine kinase associated with focal adhesions," Proceedings of the National Academy of Sciences of the United States of America, vol. 89, no. 11, pp. 5192-5196, 1992.

[36] H. Iwasaki, T. Yoshimoto, T. Sugiyama, and Y. Hirata, "Activation of cell adhesion kinase $\beta$ by mechanical stretch in vascular smooth muscle cells," Endocrinology, vol. 144, no. 6, pp. 23042310, 2003.

[37] A. P. Wheeler and A. J. Ridley, "Why three Rho proteins? RhoA, RhoB, RhoC, and cell motility," Experimental Cell Research, vol. 301, no. 1, pp. 43-49, 2004.

[38] A. Angers-Loustau, J.-F. Côté, A. Charest et al., "Protein tyrosine phosphatase-PEST regulates focal adhesion disassembly, migration, and cytokinesis in fibroblasts," The Journal of Cell Biology, vol. 144, no. 5, pp. 1019-1031, 1999.

[39] M. D. Schaller, "Cellular functions of FAK kinases: insight into molecular mechanisms and novel functions," Journal of Cell Science, vol. 123, no. 7, pp. 1007-1013, 2010.

[40] W.-C. Huang, G. B. Sala-Newby, A. Susana, J. L. Johnson, and A. C. Newby, "Classical macrophage activation up-regulates several matrix metalloproteinases through mitogen activated protein kinases and nuclear factor- $\kappa \mathrm{B}$," PLOS ONE, vol. 7, no. 8, Article ID e42507, 2012.

[41] W. Lieb, P. Gona, M. G. Larson et al., "Biomarkers of the osteoprotegerin pathway: clinical correlates, subclinical disease, incident cardiovascular disease, and mortality," Arteriosclerosis, Thrombosis, and Vascular Biology, vol. 30, no. 9, pp. 1849-1854, 2010.

[42] R. R. Rodrigues-Diez, A. B. Garcia-Redondo, M. Orejudo et al., "The C-terminal module IV of connective tissue growth factor, through EGFR/Noxl signaling, activates the NF- $\kappa$ B pathway and proinflammatory factors in vascular smooth muscle cells," Antioxidants \& Redox Signaling, vol. 22, no. 1, pp. 29-47, 2015.

[43] J. Ren, Q. Wang, S. Morgan et al., "Protein Kinase C- $\delta$ (PKC $\delta$ ) Regulates Proinflammatory Chemokine Expression through Cytosolic Interaction with the NF- $\kappa$ B Subunit p65 in Vascular Smooth Muscle Cells," The Journal of Biological Chemistry, vol. 289, no. 13, pp. 9013-9026, 2014.

[44] S. Guan, Q. Tang, W. Liu, R. Zhu, and B. Li, "Nobiletin inhibits PDGF-BB-induced vascular smooth muscle cell proliferation and migration and attenuates neointimal hyperplasia in a rat carotid artery injury model," Drug Development Research, vol. 75, no. 8, pp. 489-496, 2014.

[45] P. K. Shah, "Inflammation, neointimal hyperplasia, and restenosis: As the leukocytes roll, the arteries thicken," Circulation, vol. 107, no. 17, pp. 2175-2177, 2003.

[46] Y. Yamamoto and R. B. Gaynor, "Therapeutic potential of inhibition of the NF- $\kappa$ B pathway in the treatment of inflammation and cancer," The Journal of Clinical Investigation, vol. 107, no. 2, pp. 135-142, 2001.

[47] L. H. Cazarolli, L. Zanatta, E. H. Alberton et al., "Flavonoids: prospective drug candidates," Mini-Reviews in Medicinal Chemistry, vol. 8, no. 13, pp. 1429-1440, 2008.

[48] T. P. T. Cushnie and A. J. Lamb, "Recent advances in understanding the antibacterial properties of flavonoids," International Journal of Antimicrobial Agents, vol. 38, no. 2, pp. 99-107, 2011.

[49] R. R. de Sousa, K. C. Queiroz, A. C. Souza et al., "Phosphoprotein levels, MAPK activities and NFkappaB expression are affected by fisetin," Journal of Enzyme Inhibition and Medicinal Chemistry, vol. 22, no. 4, pp. 439-444, 2007.

[50] M. Schuier, H. Sies, B. Illek, and H. Fischer, "Cocoa-related flavonoids inhibit CFTR-mediated chloride transport across T84 human colon epithelia," Journal of Nutrition, vol. 135, no. 10, pp. 2320-2325, 2005.

[51] G. Siasos, D. Tousoulis, V. Tsigkou et al., "Flavonoids in atherosclerosis: An overview of their mechanisms of action," Current Medicinal Chemistry, vol. 20, no. 21, pp. 2641-2660, 2013.

[52] R. M. Van Dam, N. Naidoo, and R. Landberg, "Dietary flavonoids and the development of type 2 diabetes and cardiovascular diseases: Review of recent findings," Current Opinion in Lipidology, vol. 24, no. 1, pp. 25-33, 2013.

[53] X. Luo, S. Fang, Y. Xiao et al., "Cyanidin-3-glucoside suppresses TNF- $\alpha$-induced cell proliferation through the repression of Nox activator 1 in mouse vascular smooth muscle cells: involvement of the STAT3 signaling," Molecular and Cellular Biochemistry, vol. 362, no. 1-2, pp. 211-218, 2012.

[54] J. J. Lee, H. Yi, I. S. Kim et al., “(2S)-naringenin from Typha angustata inhibits vascular smooth muscle cell proliferation via a G0/G1 arrest," Journal of Ethnopharmacology, vol. 139, no. 3, pp. 873-878, 2012.

[55] Y. Hu, K. Liu, M. Yan, Y. Zhang, Y. Wang, and L. Ren, "Icariin inhibits oxidized low-density lipoprotein-induced proliferation of vascular smooth muscle cells by suppressing activation of extracellular signal-regulated kinase $1 / 2$ and expression of proliferating cell nuclear antigen," Molecular Medicine Reports, vol. 13, no. 3, pp. 2899-2903, 2016.

[56] L.-H. Zhu, L. Wang, D. Wang et al., "Puerarin attenuates high-glucose and diabetes-induced vascular smooth muscle cell proliferation by blocking PKCbeta2/Rac1-dependent signaling," 
Free Radical Biology \& Medicine, vol. 48, no. 4, pp. 471-482, 2010.

[57] Y.-J. Li and G.-H. Du, "Effects of alpinetin on rat vascular smooth muscle cells," Journal of Asian Natural Products Research, vol. 6, no. 2, pp. 87-92, 2004.

[58] L. Wei, W. Deng, Z. Cheng et al., "Effects of hesperetin on platelet-derived growth factor-BB-induced pulmonary artery smooth muscle cell proliferation," Molecular Medicine Reports, vol. 13, no. 1, pp. 955-960, 2016.

[59] L. Li, X.-B. Pang, B.-N. Chen et al., "Pinocembrin inhibits angiotensin II-induced vasoconstriction via suppression of the increase of $[\mathrm{Ca} 2+] \mathrm{i}$ and ERK1/2 activation through blocking AT1R in the rat aorta," Biochemical and Biophysical Research Communications, vol. 435, no. 1, pp. 69-75, 2013.

[60] H. J. Kim, B.-Y. Cha, B. Choi, J. S. Lim, J.-T. Woo, and J.-S. Kim, "Glyceollins inhibit platelet-derived growth factor-mediated human arterial smooth muscle cell proliferation and migration," British Journal of Nutrition, vol. 107, no. 1, pp. 24-35, 2012.

[61] D. Pinkaew, S. G. Cho, D. Y. Hui et al., "Morelloflavone blocks injury-induced neointimal formation by inhibiting vascular smooth muscle cell migration," Biochimica et Biophysica Acta (BBA) - General Subjects, vol. 1790, no. 1, pp. 31-39, 2009.

[62] K. Kim, S. Kim, S. H. Moh, and H. Kang, "Kaempferol inhibits vascular smooth muscle cell migration by modulating BMPmediated miR-21 expression," Molecular and Cellular Biochemistry, vol. 407, no. 1-2, pp. 143-149, 2015.

[63] J. $\mathrm{Xu}, \mathrm{Z} . \mathrm{Xu}$, and W. Zheng, "A review of the antiviral role of green tea catechins," Molecules, vol. 22, no. 8, 2017.

[64] F. Haghighatdoost, B. F. Nobakht M. Gh, and M. Hariri, "Effect of Green Tea on Plasma Adiponectin Levels: A Systematic Review and Meta-analysis of Randomized Controlled Clinical Trials," Journal of the American College of Nutrition, vol. 36, no. 7, pp. 541-548, 2017.

[65] D. Wang, Q. Gao, T. Wang et al., "Green tea infusion protects against alcoholic liver injury by attenuating inflammation and regulating the PI3K/Akt/eNOS pathway in C57BL/6 mice," Food \& Function, vol. 8, no. 9, pp. 3165-3177, 2017.

[66] X. W. Cheng, M. Kuzuya, T. Sasaki et al., "Green tea catechins inhibit neointimal hyperplasia in a rat carotid arterial injury model by TIMP-2 overexpression," Cardiovascular Research, vol. 62, no. 3, pp. 594-602, 2004.

[67] M. Natsume, "Polyphenols: Inflammation," Current Pharmaceutical Design, vol. 24, no. 2, pp. 191-202, 2018.

[68] F. Oliviero, A. Scanu, Y. Zamudio-Cuevas, L. Punzi, and P. Spinella, "Anti-inflammatory effects of polyphenols in arthritis," Journal of the Science of Food and Agriculture, vol. 98, no. 5, pp. 1653-1659, 2018.

[69] F. Sarubbo, S. Esteban, A. Miralles, and D. Moranta, "Effects of resveratrol and other polyphenols on SIRT1: Relevance to brain function during aging," Current Neuropharmacology, vol. 16, no. 2, pp. 126-136, 2018.

[70] H. H. Hung, Y. L. Chen, S. J. Lin et al., "A salvianolic acid B-rich fraction of Salvia miltiorrhiza induces neointimal cell apoptosis in rabbit angioplasty model," Histology and Histopathology, vol. 16, no. 1, pp. 175-183, 2001.

[71] T.-L. Yang, F.-Y. Lin, Y.-H. Chen et al., "Salvianolic acid $\mathrm{B}$ inhibits low-density lipoprotein oxidation and neointimal hyperplasia in endothelium-denuded hypercholesterolaemic rabbits," Journal of the Science of Food and Agriculture, vol. 91, no. 1, pp. 134-141, 2011.
[72] K. Y. Hur, S. H. Kim, M.-A. Choi et al., "Protective effects of magnesium lithospermate B against diabetic atherosclerosis via Nrf2-ARE-NQO1 transcriptional pathway," Atherosclerosis, vol. 211, no. 1, pp. 69-76, 2010.

[73] Y.-L. Chen, K.-F. Lin, M.-S. Shiao, Y.-T. Chen, C.-Y. Hong, and S.-J. Lin, "Magnolol, a potent antioxidant from Magnolia officinalis, attenuates intimal thickening and MCP-1 expression after balloon injury of the aorta in cholesterol-fed rabbits," Basic Research in Cardiology, vol. 96, no. 4, pp. 353-363, 2001.

[74] R. Karki, S. B. Kim, and D. W. Kim, "Magnolol inhibits migration of vascular smooth muscle cells via cytoskeletal remodeling pathway to attenuate neointima formation," Experimental Cell Research, vol. 319, no. 20, pp. 3238-3250, 2013.

[75] L. Chen, W.-Y. Wang, and Y.-P. Wang, "Inhibitory effects of lithospermic acid on proliferation and migration of rat vascular smooth muscle cells," Acta Pharmacologica Sinica, vol. 30, no. 9, pp. 1245-1252, 2009.

[76] Y.-C. Chien, G.-J. Huang, H.-C. Cheng, C.-H. Wu, and M.-J. Sheu, "Hispolon attenuates balloon-injured neointimal formation and modulates vascular smooth muscle cell migration via AKT and ERK phosphorylation," Journal of Natural Products, vol. 75, no. 9, pp. 1524-1533, 2012.

[77] Y. Lim, J.-S. Kwon, D.-W. Kim et al., "Obovatol from Magnolia obovata inhibits vascular smooth muscle cell proliferation and intimal hyperplasia by inducing p21Cip1," Atherosclerosis, vol. 210, no. 2, pp. 372-380, 2010.

[78] A. B. Kunnumakkara, D. Bordoloi, G. Padmavathi et al., "Curcumin, the golden nutraceutical: multitargeting for multiple chronic diseases," British Journal of Pharmacology, vol. 174, no. 11, pp. 1325-1348, 2016.

[79] X. Yang, D. P. Thomas, X. Zhang et al., "Curcumin inhibits platelet-derived growth factor-stimulated vascular smooth muscle cell function and injury-induced neointima formation," Arteriosclerosis, Thrombosis, and Vascular Biology, vol. 26, no. 1, pp. 85-90, 2006.

[80] Y. Zhong, J. Feng, J. Li, and Z. Fan, "Curcumin prevents lipopolysaccharide-induced matrix metalloproteinase-2 activity via the Ras/MEK1/2 signaling pathway in rat vascular smooth muscle cells," Molecular Medicine Reports, vol. 16, no. 4, pp. 4315-4319, 2017.

[81] N. Guo, F. Chen, J. Zhou et al., "Curcumin attenuates rapamycin-induced cell injury of vascular endothelial cells," Journal of Cardiovascular Pharmacology, vol. 66, no. 4, pp. 338346, 2015.

[82] M. T. Islam, "Diterpenes and Their Derivatives as Potential Anticancer Agents," Phytotherapy Research, vol. 31, no. 5, pp. 691-712, 2017.

[83] R. Kiyama, "Estrogenic terpenes and terpenoids: Pathways, functions and applications," European Journal of Pharmacology, vol. 815, pp. 405-415, 2017.

[84] R. K. Vadivelu, S. K. Yeap, A. M. Ali, M. Hamid, and N. B. Alitheen, "Betulinic Acid inhibits growth of cultured vascular smooth muscle cells in vitro by inducing g(1) arrest and apoptosis," Evidence-Based Complementary and Alternative Medicine, vol. 2012, Article ID 251362, 7 pages, 2012.

[85] N. Ferri, L. Arnaboldi, A. Orlandi et al., "Effect of S(-) perillic acid on protein prenylation and arterial smooth muscle cell proliferation," Biochemical Pharmacology, vol. 62, no. 12, pp. 1637-1645, 2001.

[86] S.-X. Weng, M.-H. Sui, S. Chen et al., "Parthenolide inhibits proliferation of vascular smooth muscle cells through induction 
of G0/G1 phase cell cycle arrest," Journal of Zhejiang University SCIENCE B, vol. 10, no. 7, pp. 528-535, 2009.

[87] E. H. Heiss, R. Liu, B. Waltenberger et al., "Plumericin inhibits proliferation of vascular smooth muscle cells by blocking STAT3 signaling via S-glutathionylation," Scientific Reports, vol. 6, no. 1, 2016.

[88] D. Kim, J. S. Kwon, Y. G. Kim et al., "Novel Oral Formulation of Paclitaxel Inhibits Neointimal Hyperplasia in a Rat Carotid Artery Injury Model," Circulation, vol. 109, no. 12, pp. 1558-1563, 2004.

[89] M. V. Blagosklonny, Z. Darzynkiewicz, H. D. Halicka et al., "Paclitaxel induces primary and postmitotic G1 arrest in human arterial smooth muscle cells," Cell Cycle, vol. 3, no. 8, pp. 10501056, 2004.

[90] T.-J. Kim, Y. Lim, D.-W. Kim et al., "Epothilone D, a microtubule-stabilizing compound, inhibits neointimal hyperplasia after rat carotid artery injury by cell cycle arrest via regulation of G1-checkpoint proteins," Vascular Pharmacology, vol. 47, no. 4, pp. 229-237, 2007.

[91] L. Wu, G. Wang, S. Tang, G. Long, and T. Yin, "Protection of Endothelial Cells, Inhibition of Neointimal Hyperplasia by $\beta$-elemene in an Injured Artery," Cardiovascular Drugs and Therapy, vol. 25, no. 3, pp. 233-242, 2011.

[92] Q. Cao, Y. Jiang, J. Shi et al., “ Artemisinin inhibits tumour necrosis factor- ", Clinical and Experimental Pharmacology and Physiology, vol. 42, no. 5, pp. 502-509, 2015.

[93] H.-Y. Wang, R.-P. Huang, P. Han et al., "The effects of artemisinin on the proliferation and apoptosis of vascular smooth muscle cells of rats," Cell Biochemistry \& Function, vol. 32, no. 2, pp. 201-208, 2014.

[94] C. E. Mair, R. Liu, A. G. Atanasov et al., "Piperine Congeners as Inhibitors of Vascular Smooth Muscle Cell Proliferation," Planta Medica, vol. 81, no. 12-13, pp. 1065-1074, 2015.

[95] H. Tanabe, H. Suzuki, A. Nagatsu, H. Mizukami, Y. Ogihara, and M. Inoue, "Selective inhibition of vascular smooth muscle cell proliferation by coptisine isolated from Coptis rhizoma, one of the crude drugs composing Kampo medicines Unsei-in," Phytomedicine, vol. 13, no. 5, pp. 334-342, 2006.

[96] K. Wang, L. Wen, W. Peng et al., "Vinpocetine Attenuates Neointimal Hyperplasia in Diabetic Rat Carotid Arteries after Balloon Injury," PLoS ONE, vol. 9, no. 5, p. e96894, 2014.

[97] Y. Cai, W. E. Knight, S. Guo, J.-D. Li, P. A. Knight, and C. Yan, "Vinpocetine suppresses pathological vascular remodeling by inhibiting vascular smooth muscle cell proliferation and migration," The Journal of Pharmacology and Experimental Therapeutics, vol. 343, no. 2, pp. 479-488, 2012.

[98] A. Nagler, H.-Q. Miao, H. Aingorn, M. Pines, O. Genina, and I. Vlodavsky, "Inhibition of collagen synthesis, smooth muscle cell proliferation, and injury-induced intimal hyperplasia by halofuginone," Arteriosclerosis, Thrombosis, and Vascular Biology, vol. 17, no. 1, pp. 194-202, 1997.

[99] J. Han, Y. Kim, S. Jung et al., "Murrayafoline A Induces a G," The Korean Journal of Physiology \& Pharmacology, vol. 19, no. 5, pp. 421-426, 2015.

[100] X. Dong, J. Fu, X. Yin et al., "Emodin: A Review of its Pharmacology, Toxicity and Pharmacokinetics," Phytotherapy Research, vol. 30, no. 8, pp. 1207-1218, 2016.

[101] X. Wang, Y. Zou, A. Sun et al., "Emodin induces growth arrest and death of human vascular smooth muscle cells through reactive oxygen species and p53," Journal of Cardiovascular Pharmacology, vol. 49, no. 5, pp. 253-260, 2007.
[102] S. Wang, Y. Liu, F. Fan, J. Yan, X. Wang, and J. Chen, "Inhibitory effects of emodin on the proliferation of cultured rat vascular smooth muscle cell-induced by angiotensin II," Phytotherapy Research, vol. 22, no. 2, pp. 247-251, 2008.

[103] X. Pang, J. Liu, Y. Li, J. Zhao, X. Zhang, and U. Sen, "Emodin Inhibits Homocysteine-Induced C-Reactive Protein Generation in Vascular Smooth Muscle Cells by Regulating PPAR $\gamma$ Expression and ROS-ERK1/2/p38 Signal Pathway," PLoS ONE, vol. 10, no. 7, p. e0131295, 2015.

[104] S. Heo, H. Yun, W. Park, and S. Park, "Emodin inhibits TNF$\alpha$-induced human aortic smooth-muscle cell proliferation via caspase- and mitochondrial-dependent apoptosis," Journal of Cellular Biochemistry, vol. 105, no. 1, pp. 70-80, 2008.

[105] L. Meng, D. Yan, W. Xu, J. Ma, B. Chen, and H. Feng, "Emodin inhibits tumor necrosis factor-alpha-induced migration and inflammatory responses in rat aortic smooth muscle cells," International Journal of Molecular Medicine, vol. 29, no. 6, pp. 999-1006, 2012.

[106] K. Xu, M. K. Al-ani, C. Wang et al., "Emodin as a selective proliferative inhibitor of vascular smooth muscle cells versus endothelial cells suppress arterial intima formation," Life Sciences, vol. 207, pp. 9-14, 2018.

[107] Y. Chung, C. Pan, C. C. Wang et al., "Methyl Protodioscin, a Steroidal Saponin, Inhibits Neointima Formation in Vitro and in Vivo," Journal of Natural Products, vol. 79, no. 6, pp. 16351644, 2016.

[108] X. Li, J.-R. Du, Y. Yu, B. Bai, and X.-Y. Zheng, “Tanshinone IIA inhibits smooth muscle proliferation and intimal hyperplasia in the rat carotid balloon-injured model through inhibition of MAPK signaling pathway," Journal of Ethnopharmacology, vol. 129, no. 2, pp. 273-279, 2010.

[109] N. Ferri, K. Yokoyama, M. Sadilek et al., "Ajoene, a garlic compound, inhibits protein prenylation and arterial smooth muscle cell proliferation," British Journal of Pharmacology, vol. 138, no. 5, pp. 811-818, 2003.

[110] L. Zhu, H. Guan, C. Cui et al., "Gastrodin inhibits cell proliferation in vascular smooth muscle cells and attenuates neointima formation in vivo," International Journal of Molecular Medicine, vol. 30, no. 5, pp. 1034-1040, 2012.

[111] F. Jiang, R. Jiang, X. Zhu, X. Zhang, and Z. Zhan, “Genipin Inhibits TNF- $\alpha$-Induced Vascular Smooth Muscle Cell Proliferation and Migration via Induction of HO-1," PLOS ONE, vol. 8, no. 8, Article ID e74826, 2013.

[112] Z. Ma, Y. Gao, Y. Wang, H. Tan, C. Xiao, and S. Wang, "Ginsenoside Rg1 inhibits proliferation of vascular smooth muscle cells stimulated by tumor necrosis factor- $\alpha 1$," Acta Pharmacologica Sinica, vol. 27, no. 8, pp. 1000-1006, 2006.

[113] Y. Gao, J. Deng, X.-F. Yu, D.-L. Yang, Q.-H. Gong, and X.-N. Huang, "Ginsenoside Rgl inhibits vascular intimal hyperplasia in balloon-injured rat carotid artery by down-regulation of extracellular signal-regulated kinase 2," Journal of Ethnopharmacology, vol. 138, no. 2, pp. 472-478, 2011.

[114] H.-S. Zhang and S.-Q. Wang, "Ginsenoside Rg1 inhibits tumor necrosis factor- $\alpha$ (TNF- $\alpha$ )- induced human arterial smooth muscle cells (HASMCs) proliferation," Journal of Cellular Biochemistry, vol. 98, no. 6, pp. 1471-1481, 2006.

[115] H. Joa, S. Vogl, A. G. Atanasov et al., "Identification of ostruthin from peucedanum ostruthium rhizomes as an inhibitor of vascular smooth muscle cell proliferation," Journal of Natural Products, vol. 74, no. 6, pp. 1513-1516, 2011. 
[116] M. Mao, H. Lei, Q. Liu et al., "Lycopene inhibits neointimal hyperplasia through regulating lipid metabolism and suppressing oxidative stress," Molecular Medicine Reports, vol. 10, no. 1, pp. 262-268, 2014.

[117] S.-H. Yoo, Y. Lim, S.-J. Kim et al., "Sulforaphane inhibits PDGFinduced proliferation of rat aortic vascular smooth muscle cell by up-regulation of p53 leading to G1/S cell cycle arrest," Vascular Pharmacology, vol. 59, no. 1-2, pp. 44-51, 2013.

[118] D. Gfeller, A. Grosdidier, M. Wirth, A. Daina, O. Michielin, and V. Zoete, "SwissTargetPrediction: A web server for target prediction of bioactive small molecules," Nucleic Acids Research, vol. 42, no. 1, pp. W32-W38, 2014.

[119] A. Yamauchi, A. Kobayashi, H. Oikiri, and Y. Yokoyama, "Functional role of the Tau protein in epithelial ovarian cancer cells," Reproductive Medicine and Biology, vol. 16, no. 2, pp. 143151, 2017.

[120] J. Yang, Y. Yu, W. Liu, Z. Li, Z. Wei, and R. Jiang, "Microtubuleassociated protein tau is associated with the resistance to docetaxel in prostate cancer cell lines," Research and Reports in Urology, vol. 9, pp. 71-77, 2017. 


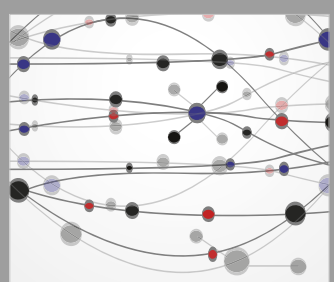

The Scientific World Journal
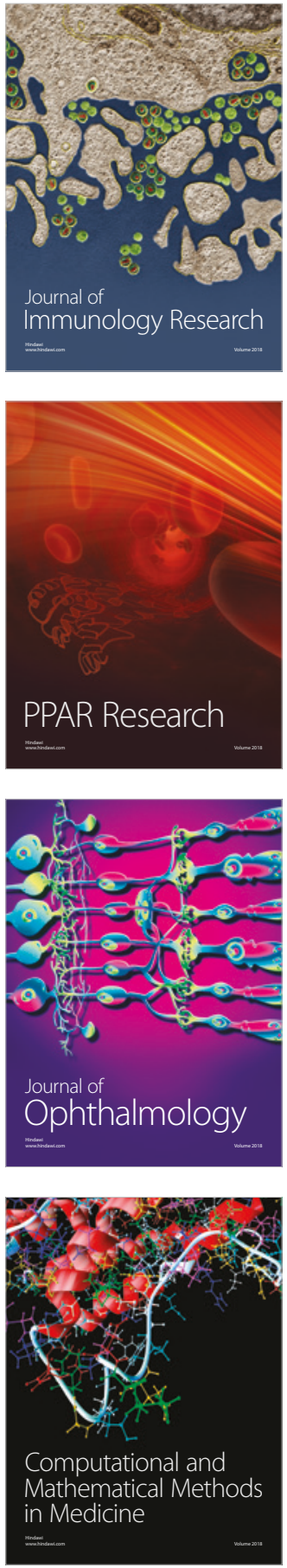

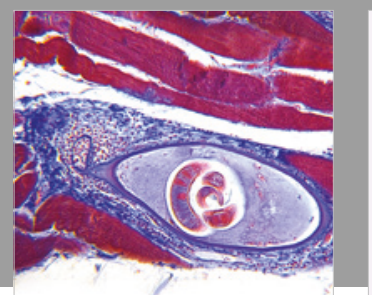

Gastroenterology Research and Practice

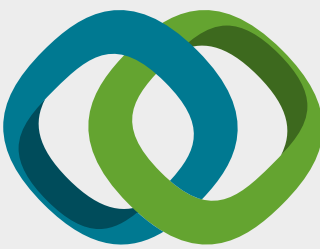

\section{Hindawi}

Submit your manuscripts at

www.hindawi.com
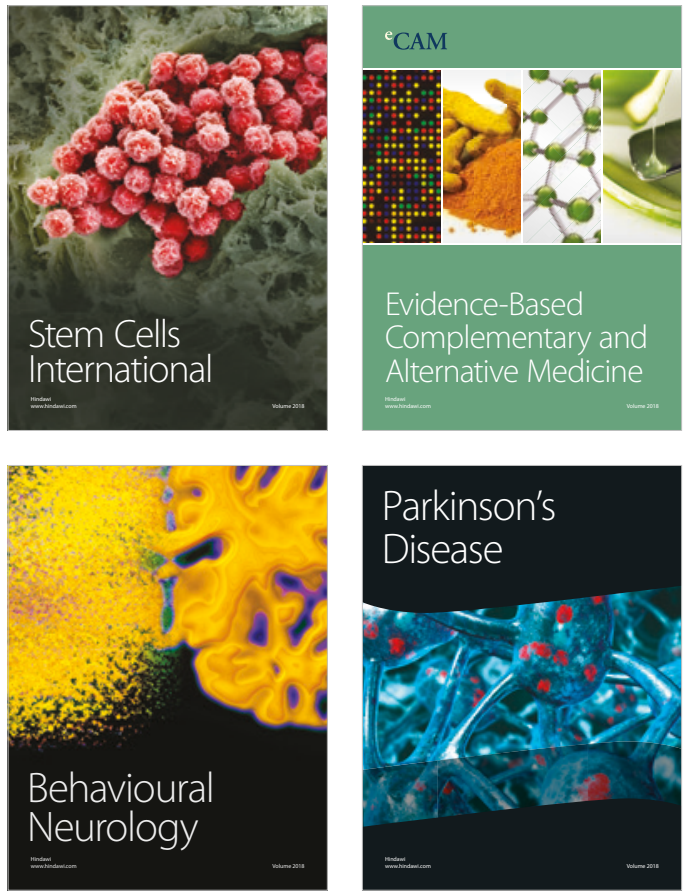

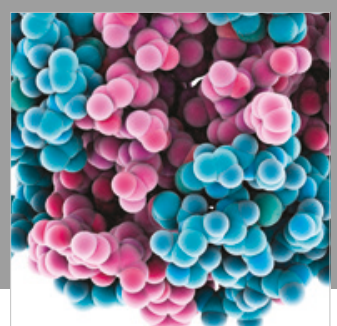

ournal of

Diabetes Research

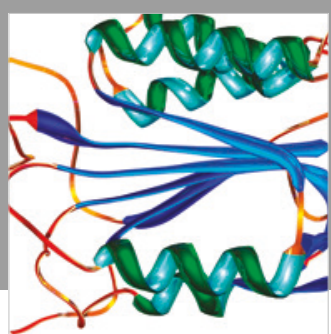

Disease Markers
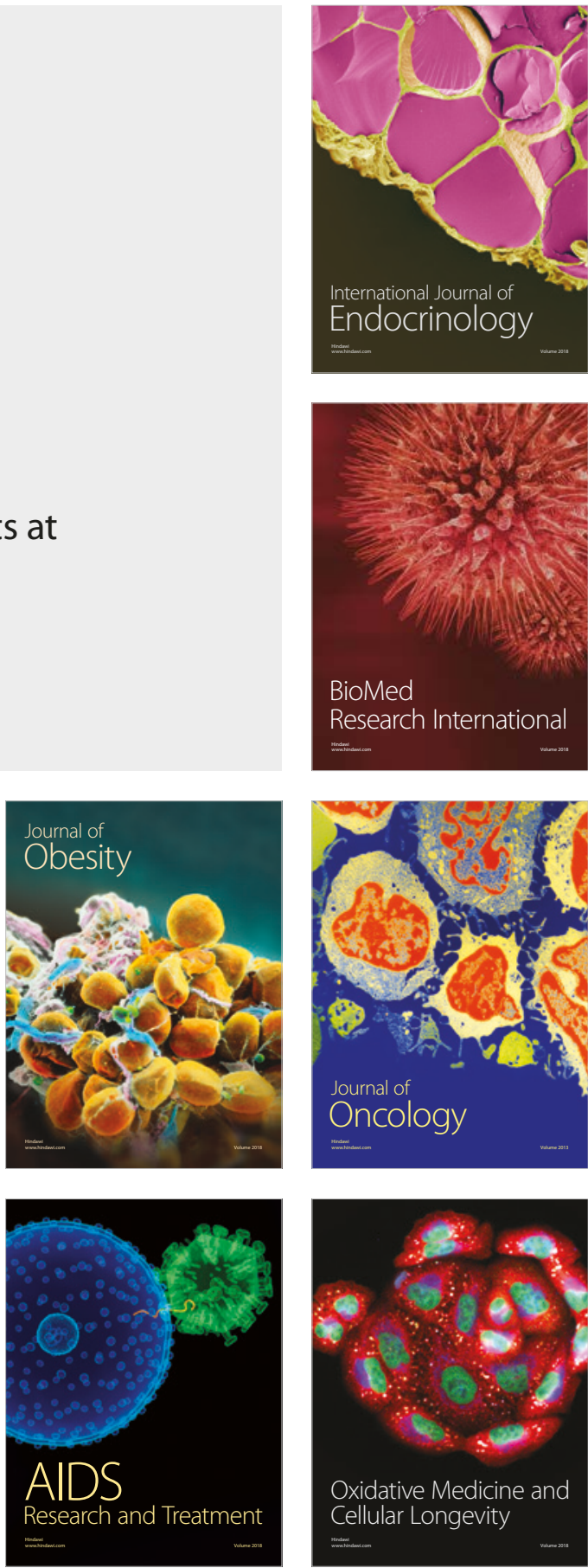